\title{
Christianity, colonialism, and cross-cultural translation: Lancelot Threlkeld, Biraban, and the Awabakal
}

\author{
Anne Keary
}

This essay aims to reconstruct a cross-cultural conversation about sacred matters between Lancelot Threlkeld, a missionary with the London Missionary Society (LMS), and Biraban, a leading man of the Awabakal of eastern Australia. Between 1825 and 1841, Threlkeld devoted himself to learning the language of the Awabakal in hopes of converting them to Christianity, while Biraban, his principal language teacher, helped him translate Christian concepts and educated him about Awabakal traditions. The records of their endeavours are preserved, albeit in an edited and fragmented form, in the missionary's grammars, vocabularies and Scriptural translations. A close examination of these linguistic texts reveals, in outline, the dynamics of a complex, multi-faceted exchange. Read carefully - and in conjunction with Threlkeld's other writings - these texts yield new insights into the cross-cultural translation and indigenous reception of Christianity during an early period of British colonisation. ${ }^{1}$

Threlkeld's voluminous writings have been the subject of numerous studies. Most scholars have focused on his letters and public reports. Threlkeld

1 A note on terminology: most contemporary scholars use the name Awabakal to refer to both the people who lived around Lake Macquarie and their language. However, it should be noted that the name Awabakal is a relatively recent invention. It appears to have been given to the 'Lake Macquarie' people by John Fraser when he edited and republished Threlkeld's writings under the title The Australian Language as Spoken by the Awabakal, the People of Lake Macquarie, being an account of their language, traditions, and customs (Threlkeld 1892). Fraser may have created this name on the assumption that 'Awaba' was the indigenous name for Lake Macquarie and that Aboriginal people in the east used ' $k a l$ ' to denote belonging to a place. But the term 'Awaba' was Fraser's addition to his reprint of Threlkeld's original 1834 Grammar and Threlkeld himself never used the name Awabakal. In fact, according to a visiting philologist, Horatio Hale, Threlkeld was not aware of any name that the people used to refer to themselves (Hale 1846: 482). From Threlkeld's own translations, it would appear that the people more often spoke of themselves as people belonging to Mu-lu-bin-ba, the name of the site upon which the British established Newcastle (Threlkeld 1834b: 15). Moreover, Threkeld records 'Nik-kin-ba' or 'a place of coals' as a name for the lake region (Threlkeld 1834b: 83; 'Reminiscences' Threlkeld 1974: 64). More recently, Amanda Lissarague has termed the language spoken by the Awabakal as the 'Hunter River and Lake Macquarie language' or HRLM on the basis that Threlkeld often used this descriptive phrase when referring to the language and that the language was closely related to dialects spoken by neighbouring peoples in the region. (Lissarague 2006: 12-14. While some scholars now use this term to refer to the language, (eg Carey 2009), many linguists continue to use the name Awabakal (See McGregor 2008). In this essay, then, for ease of expression, I will use Awabakal to refer to both the language and the people. 
is a central figure in Henry Reynolds' account of those all-too-few British humanitarians who exposed and protested colonial violence against Aboriginal people. Threlkeld is also central to Anna Johnston's study of missionary writing in the Pacific. Using the conceptual tools of post-colonial theory, Johnston has analysed the complex ways in which Threlkeld's representations of indigenous Australians both supported and unsettled dominant understandings of race and gender in colonial society. It is only recently that scholars have turned their attention to Threlkeld's language studies. Amanda Lissarague has used the works of Threlkeld and others to produce a grammar and linguistic analysis of the language spoken by the Awabakal people. From an historical perspective, David Roberts has shown how Threlkeld used his linguistic works to defend and promote his evangelical endeavours, while Hilary Carey has examined Threlkeld's grammars and vocabularies in the context of the colonial study of Aboriginal languages, and more recently as texts that are revealing of 'conversations in the contact zone' and the disintegration of indigenous 'camp life'. Meanwhile, in a new study of Aboriginal engagement with the colonisers' culture of literacy, Penny van Torn has discussed Threlkeld and Biraban's relationship as translators and Biraban's response to Christianity, but without close analysis of the linguistic texts themselves. ${ }^{2}$

This essay extends and diverges from these studies. It focuses primarily on Threlkeld's linguistic works but it is specifically concerned with what these texts can tell us about the cross-cultural translation of Christian and indigenous religious concepts during the early years of colonisation. As an attempt at retrieving and reconstructing Aboriginal voices from British sources, it is ethnohistorical in its methods and goals. ${ }^{3}$ Missionary linguistic texts, as scholars

2 Reynolds 1998: 60-69; Johnston 2003, Chs 8 and 9; Lissarague 2006; Roberts 2008; Carey 2004, 2009: 168, 174; van Toorn 2006: 39-52. Niel Gunson's introduction and editorial notes for his two volume collection of Threlkeld's writings remain an immensely rich source of information about Threlkeld and the Awabakal during the mission years but Gunson did not examine Threlkeld's linguistic records, see Threlkeld 1974.

3 For the most part, studies of Aboriginal missions have focused on missions in the later nineteenth and twentieth centuries and it is only recently that Australian scholars have adopted an ethnohistorical approach to mission sources. Historians have tended to dismiss the early colonial missions as short-lived failures: Swain and Trompf 1995: 79-86; Woolmington 1988. Inga Clendinnen, in her recent and widely praised ethnohistory of encounters between Aborigines and the First Fleet, argued that the kind of reconstruction of indigenous religious thinking that she undertook in her previous study of Spanish/Maya relations was 'impossible for [Australia] ... not least because after the first few years the Australians ceased to be of much interest to the British, while in Mexico the friars remained committed to the pursuit of souls'. However, Clendinnen ignores the fact that missionaries in early colonial Australia such as Threlkeld, did, in fact, leave records of their encounters with Aboriginal peoples: Clendinnen 2005: 5. More recently, scholars have shown how an ethnohistorical approach can illuminate the history of Aboriginal responses to evangelisation. For the early period see Carey and Roberts 2002; Brock 2003; and for interesting ethnohistorical work on the indigenous reception of Christianity in the late nineteenth and twentieth centuries see Austin Broos 1994; Magowan 2003; Swain and Rose 1988; Van Gent 2003. More generally, on the need to consider Aboriginal engagements with mission Christianity as dynamic and dialectal see Ranger 2005; Brock 2005 and for an informative discussion of ethnohistory in Australia see Brock 2004. In North America, Africa, and the Pacific, the ethnohistorical study of missionary sources for insight into indigenous responses to 
in other fields have shown, were hybrid, cross-cultural productions. ${ }^{4}$ They necessarily emerged, as Derek Peterson writes, 'out of a sustained dialogue with native others', and bear the marks, however refracted, of indigenous interests and intentions. ${ }^{5}$ But these texts were also, of course, colonial representations of indigenous peoples and their languages, and they were intended, too, as instruments of colonial transformation. ${ }^{6}$ In this essay, then, I read Threlkeld's linguistic works as both colonial representations of indigenous people and products of interaction with them in a colonial environment. In doing so, I consider how colonial assumptions about indigenous inferiority were variously reproduced and undermined in Threlkeld's representations of the Awabakal and their language and, at the same time, how the texts themselves, as works of translation, are revealing of a mutual, if unequal, engagement with different structures of meaning. This engagement was necessarily bound up with colonial relations: it can be analysed in terms of knowledge and power, domination and resistance, but such analysis should be particularised. It should also be open to the possibility that the engagement produced other ways of relating, other ways of knowing. As Nicholas Thomas has reminded us, it is important to recognise that 'colonialism' and 'culture' - and, one might add, cross-cultural interaction 'were often deeply mutually implicated without reducing one to the other'. And that 'the process of colonization', and evangelisation, 'may be conditioned, in a profound way, by singular features of indigenous cultural structures and power relations'.7

The study of Threlkeld's grammars and vocabularies presents an opportunity to analyse such processes at the localised level of interpersonal, ethnographic encounters. Specifically, then, I examine these texts to show how linguistic exchange provided Biraban and others with an opportunity to redefine their relationship to the missionary and assert and defend the significance of their sacred sites and Ancestral Beings in the face of colonisation; how the Awabakal and other Aboriginal peoples interpreted the missionary's Christian deity; and how, perhaps most intriguingly, Biraban translated key Christian concepts in terms of male sacred knowledge as Awabakal ceremonial life began to break down. Further, I look at how these texts illuminate the complexity of the missionary's own relationship to indigenous culture: his dependence on, and even growing understanding of, the very cultural categories he sought to displace.

Christianity is well established. Some of the works that I have found particularly useful include Burkhart 1989; Greer 2005; Landau 1995; Neylan 2003. For an interesting discussion of the critical reading of missionary sources see Douglas 2001.

4 Insightful studies of missionary linguistic texts include: Fabian 1986; Rafael 1993; Peterson 1999; Worger 2001; Gardner 2006.

5 Peterson 1999: 36.

6 Fabian 1986; Gilmour 2006.

7 Thomas 1994: 41, 64. 


\section{Establishing a mission in a colonial world}

In order to understand the dynamics of Threlkeld and Biraban's cross-cultural dialogue it is necessary to understand the early history of the mission and the position each man occupied in a rapidly changing colonial world. Each came to the encounter with very different understandings and expectations of the other.

When Threlkeld arrived in Australia in late 1824, he was already an experienced missionary. The son of an English brush-maker and a former circus performer, Threlkeld had joined the mainly non-conformist LMS in 1813 following a life-altering conversion. After receiving some training in theology and English grammar, he had been sent by the LMS Board to its mission in the Society Islands. ${ }^{8}$ There, on the island of Raitaea, Threlkeld had learned the local indigenous language, translated the gospel, established a school, and, according to his own report, succeeded in baptising 1,100 individuals. ${ }^{9}$ A dedicated missionary of the dissenting tradition, his experiences on Raiatea did not alter his belief that all non-Christian, non-European others were depraved, uncivilised heathens who could only be saved - and then civilised - through a knowledge of the gospel. ${ }^{10}$ But Threlkeld had also proved himself to be a 'difficult' man while in the Society Islands, an individual capable of questioning authority when he believed principle required it. ${ }^{11}$

Threlkeld initially expected his stay in New South Wales to be temporary. He had come to New South Wales with a travelling LMS Deputation, headed by Daniel Tyerman and George Bennet, in hopes of finding a new partner after the death of his first wife. However, events in the colony led him to alter his plans. Soon after their arrival, the Deputation began making inquiries about the Aboriginal people of the country. They were shocked by the physical and moral condition of the indigenous people they encountered. They were also struck by how little evangelical work had been undertaken on their behalf. Earlier colonial attempts to convert and 'civilise' Aboriginal people had focused on teaching children in the homes of clergy or in the Parramatta Native Institution and they had met with little success. ${ }^{12}$ As a consequence, the Deputation learned, most of the colonial clergy, particularly the senior Anglican minister, Samuel Marsden, had come to view Aboriginal people as incapable of 'civilisation' and without hope of salvation, 'as untractable as the kangaroos and oppossums ... of this strange country'. ${ }^{13}$ And while the clergy were pessimistic, they were informed that many among the growing settler population viewed Aboriginal people

8 For biographical information on Threlkeld see Gunson, 'Introduction', Threlkeld 1974 I: 15-21.

9 London Missionary Society 1824: 20-21.

10 For Threlkeld's beliefs on the state of the non-Christian see Threlkeld's 'Answers at his ordination in London in 1815', Mitchell Library, London Missionary Society 'South Sea Mission' papers c1800-1915, A 381, Reel CY 877, and his reports on the Raiatean mission in Threlkeld and Williams 1822: 75-77. On Nonconformist missionary ideology in the nineteenth century see Hall 2002: 86-98; Porter 1999.

11 On Threlkeld's role as colonial critic see Johnston 2006.

12 For an account of previous efforts to 'civilise' Aboriginal people in the colonial period see Brook and Kohen 1991: Ch 3; Gunson, 'Introduction', Threlkeld 1974 I: 10-13; Johnston 2003: 169-172.

13 Tyerman and Bennet 1832: 268. 
with open hostility and had even publicly advocated their extermination. ${ }^{14}$ The Deputation, however, was undeterred. Although they were inclined to accept the colonial view that the Aboriginal people were the 'lowest class of human beings', they insisted, nonetheless, that they were human beings and therefore possessed of souls to be saved. ${ }^{15}$ Tyerman and Bennet therefore proposed a new mission and asked Threlkeld to stay on. They also proposed the adoption of new strategies. Noting that the failed evangelical efforts of the past had focused on teaching Aboriginal people English, the Deputation argued that if the gospel was preached to the 'Natives' 'in their own tongue', as on the Society Islands, a new venture might succeed. ${ }^{16}$ Further, they argued that a mission station should be established at a remove from, rather than within, colonial settlements, so that the 'Natives' would be less subject to the 'immoral' influences of the convict population. ${ }^{17}$ After considering a number of sites, the Deputation chose land near Lake Macquarie, 20 miles south of Newcastle, and applied to the colonial government for a grant of 10,000 acres. With Governor Brisbane's support, the new mission was initiated. ${ }^{18}$

The object of Threlkeld's evangelical endeavour, the Awabakal, occupied a very different position in the evolving colonial order. Certainly, they were not as untouched by colonisation as the Deputation would have liked to believe. Since 1804 when the penal colony of Newcastle was founded on their fern-gathering grounds of Mulubinba, they had been in contact with the British, mainly as occasional traders. ${ }^{19}$ Then, when Governor Brisbane decided to close the penal colony in 1821 and Newcastle became a port for free settlers, the Awabakal witnessed as a wave of colonists invaded the lands of the neighbouring Wonaruah and Geawegal peoples along the Hunter River valley. ${ }^{20}$ When these peoples resisted, the colonial government sent in military forces to 'secure' the valley, providing a stark object lesson in terror to all indigenous peoples in the region. ${ }^{21}$ While the Awabakal were still able to fish and hunt on their own lands and, importantly, maintain their spiritual connections to their country during

14 See Threlkeld to Burder and Hankey, 2 February 1825, Threlkeld 1974 II: 178.

15 Tyerman and Bennet 1832: 260.

16 Tyerman and Bennet 1832: 279.

17 Extract from a letter to Brisbane from Tyerman and Bennet, 8 February 1825, London Missionary Society 1829: 294. On the decision to establish the mission near Newcastle see also London Missionary Society 1825: 17.

18 'Deed of Trust to Aboriginal Mission by Sir Thomas Brisbane', Historical Records of Australia [hereafter HRA], series I, vol XI: 512-513.

19 On Mulubinba as an Awabakal site see Threlkeld 1834a, 'A Selection of Prayers for the Morning and Evening...', Mitchell Library, ML ZA 1446, Reel CY 2214 [hereafter Threlkeld 1834a]: 15-16, 1850: 47. On Awabakal territory and the groups that make up the Awabakal see Austin 1995: 4-5; Gunson in Threlkeld 1974 I: 72 . For a general account of contact between the Awabakal and the British at Newcastle, see Roberts nd. Although relations were generally peaceful, there were incidents of violence, see Menzies 1804.

20 For an account of tribal systems in the Hunter region see Brayshaw 1986: 36-51. On the relationship between the Awabakal and other south-eastern Australian groups see Gunson, 'Introduction', Threlkeld 1974 I: 3-5; Miller 1985: 12.

21 On the invasion of the Hunter River Valley see Perry 1963: 66; Dangar 1828: 126-7. For reports of the military operation in the Hunter River Valley see Darling, 'Dispatches, September 1826', Mitchell Library, A 1197, Reel CY 522. 
this time, they too found themselves subject to invasion. ${ }^{22}$ Coinciding with the establishment of the mission, six colonists took up grants of land around Lake Macquarie between 1826 and 1829. Although this takeover was more limited than the invasion of the Hunter River valley, it still had a significant impact. Soldiers and the convict labourers assigned to work on settlers' pastoral runs, attacked Aboriginal men and assaulted Aboriginal women. ${ }^{23}$ This escalation in violence was also accompanied by an increasingly virulent racism. Threlkeld reported that many colonists in the region had come to regard Aboriginal people as not even human, but as 'a species of Baboon' ${ }^{24}$

In this increasingly hostile environment, Threlkeld's position became more complicated. Having established his mission on Awabakal land, at a site they called 'Bah-tah-bah', he was, in many respects, a colonist too. ${ }^{25} \mathrm{He}$ also continued to hold to the colonial - and evangelical - view that the 'heathen' Aborigines lived in a state of 'darkness, error, superstition, and misery', and, in many respects, his goal of converting them to Christianity and instructing them in 'the arts of civilised life', supported colonial interests in that it was necessarily aimed at encouraging the Awabakal to reject their spiritual connections to the land and accept the colonising society's religion and settled, agricultural way of life. ${ }^{26}$ However, as Threlkeld went about building his mission house for his children and his new wife, Sarah Arndell, he became more and more involved in the lives and conflicts of the Awabakal. Motivated by conscience and an evangelical belief in the fundamental, and therefore redeemable, humanity of Aboriginal people, ${ }^{27}$ he became the Awabakal's defender. He again proved himself to be a 'difficult' man by vehemently and publicly rejecting the most racist views of the colonists, declaring that the Awabakal possessed 'an equal share of intellectual power with others of the human race'.$^{28} \mathrm{He}$ also reported and denounced colonial attacks against Aboriginal people. ${ }^{29}$ This stance earned him the growing confidence of the Awabakal who increasingly looked to him as a protector, but his efforts on their behalf drew the hostility of the settler majority: the attorney-general, Saxe Bannister, warned him that 'there were many who would banish [him] from the Colony and prevent every attempt of a Missionary nature among the Blacks if

22 On the continued performance of Awabakal rituals in this early period see Threlkeld 'London Missionary Society Report, December 1825', Threlkeld 1974 II: 189-193.

23 On the colonisation of Awabakal country see Clouten 1967: 52.

24 'Memoranda, 14 December, 1825', Threlkeld 1974 I: 91.

25 On 6 June 1825, Threlkeld wrote in his 'Public Journal' of locating a favourable site for his mission, noting 'The Aborigines call the place Biddobar.' He later spelled it 'Bah-tah-bah'. See Threlkeld 1974 I: 90, 1974 II: 215.

26 For Threlkeld's views on the state of the Aborigines see his 'London Missionary Society Report, December 1825', Threlkeld 1974 II: 189. For a statement of the goals of his missionary project see his instructions in Tyerman and Bennet 1825.

27 As he wrote to the LMS Directors 'If I do not speak then my conscience says I become accessary [sic] to their death - God will give me wisdom and prudence': Threlkeld to G Burder and WA Hankey, 4 September 1826, Threlkeld 1974 II: 213

28 Threlkeld, 'London Missionary Society Report, Aboriginal Mission, New South Wales, December 1825', Threlkeld 1974 I: 190.

29 Reynolds 1998: 60-69. 
they could' ${ }^{30}$ As he commenced his work as a missionary, then, Threlkeld began to shift positions and perspectives as he variously condemned and supported colonial interests, disparaged and defended the Awabakal. ${ }^{31}$

The other figure who emerged as a crucial intermediary for the Awabakal in this period was Biraban. If Threlkeld came to Awabakal country as an experienced missionary, Biraban, his language teacher, met him as an experienced interpreter and go-between. Born around 1800, Biraban had been taken by the British some time during his boyhood and assigned as a servant to a Captain John M Gill at the military barracks in Sydney. As a mark of his claim to the boy, Gill renamed him M'Gill. When Gill returned to England he attached Biraban to a Captain Francis Allman who took him first to Port Macquarie in 1821, and then to Newcastle in 1824. During these years Biraban developed his cross-cultural skills, working as an interpreter, guide and 'bush constable' tracking runaway convicts. He learned to speak English fluently and acquired a working knowledge of the ways of the colonists. It was these skills, no doubt, that led to him being assigned, probably by Allman, to help Threlkeld learn the language of the Awabakal and build his mission station. ${ }^{32}$

For Biraban, relocating to Newcastle with Allman presented an opportunity to return to his own country and people. As Threlkeld's records show, at the same time as he began assisting the missionary, he re-established relations with his band. This was marked, in 1826, by his initiation. Threlkeld reported: 'A few weeks back Be-rah-bahn returned from a ceremony performed in the mountains, which has initiated him into all the rights of an Aborigine. ${ }^{33}$ In this ceremony, elders would have instructed Biraban in the exclusive spiritual knowledge of men and a karakul or medicine man would have knocked out one of his front teeth to mark his initiated state. ${ }^{34}$ Undoubtedly Biraban was older than the other youths who went through the ceremony at the same time, but for all Awabakal men, initiation was both a transformative rite and an important first stage in an

30 Saxe Bannister to Threlkeld, 10 August 1826, Threlkeld 1974 II: 213. However, it should be noted that while Threlkeld condemned colonial assaults against the Aborigines, he did not question their right to take possession of the country and 'improve' it. Indeed he believed they should be protected in their appropriation of Aboriginal land. During one outbreak of Aboriginal-settler conflict, he recommended that that a 'force should go overland to strike terror by appearance only, and convince the settlers that they will be protected', Threlkeld 1974 II: 93-94.

31 On Threlkeld's complicated position in colonial society see Johnston 2003: Ch 9.

32 On Biraban's early life see Threlkeld 1974 I: 6. Francis Allman was a trustee of the LMS mission so it is likely that he encouraged Biraban to assist Threlkeld.

33 Threlkeld, 'Second Half Yearly Report of the Aboriginal Mission Supported by the London Missionary Society ... June 21st, 1826', Threlkeld 1974 II: 206.

34 On men's initiation rites in Aboriginal Australia see Elkin 1977: 3-5; Berndt and Berndt 1964: 136-157; Howitt 1904: 509-642. Threlkeld noted that the ceremony was restricted to men: women were 'not admitted to see the ceremony': 'Second Half Yearly Report of the Aboriginal Mission Supported by the London Missionary Society ... June 21st, 1826', Threlkeld 1974 II: 206. Also note that karakul was an Awabakal word, see Threlkeld 1834a: 88. He did, however, use 'korarje' in his earlier writings and this term, or its variant, 'karadji' is used by Elkin in his study of Aboriginal 'Clever men'. 
ongoing process of acquiring spiritual knowledge. In Awabakal society, status and knowledge were inextricably linked: the more sacred knowledge men possessed, the more authority they exercised. ${ }^{35}$

Threlkeld's report of Biraban's initiation was detailed and an early indication of his interest in Awabakal cultural practices - even as he condemned them as 'cruel and ... vain'. ${ }^{36}$ Several of his observations are worth noting. First, he reported that Biraban and two other boys were required to sleep on the grave of a recently deceased girl for the purpose of obtaining the bone used by the karakul for tooth avulsion. ${ }^{37}$ This suggests that elders singled out Biraban and the other youths for a special test: the custom of sleeping on a grave in order to obtain the bone was reserved for those considered to be potential karakul. ${ }^{38}$ Threlkeld later learned that for the Awabakal, the bonegiver was the Ancestral Being Koun, although the spirit of a deceased person might also be involved. On this occasion, Threlkeld reported that the 'spirit of the girl came to one of them and gave them the bone', a statement that suggests Biraban was passed over. ${ }^{39}$ Nonetheless, the fact that he was tested indicates that the elders regarded him as a potentially powerful individual. A further point to be noted is that this was the first time Threlkeld recorded the name 'Be-rah-bahn', an indication that Biraban may have been given this name as a sign of his initiated state. Possibly this was his totemic name: Threlkeld later learned that the name meant 'eaglehawk' ${ }^{40}$

Biraban's return to Awabakal country, his initiation, and his subsequent marriage to a woman named 'Ti-pah-ma-ah' made him a full member of his band. ${ }^{41}$ In this respect he was establishing a position according to custom, but, through other activities, he was carving out a new position for himself. Building upon his knowledge of the colonists and his new role as Threlkeld's language teacher, Biraban became an advocate and go-between for his people. It was Biraban who reported assaults on Aboriginal people to Threlkeld who, in turn, reported them to the colonial authorities. And when the British distributed goods to Aboriginal people, it was Biraban who acted as their Awabakal contact. In 1829, for instance, his name heads a list of men 'assembled at ... Newcastle,

35 On the link between knowledge and status in many Aboriginal societies see Stanner 1979: 39.

36 Threlkeld, London Missionary Society: Aboriginal Mission, New South Wales, December 1852 [1825]', Threlkeld 1974: 194.

37 Threlkeld, 'Second Half Yearly Report of the Aboriginal Mission Supported by the London Missionary Society ... June 21st, 1826', Threlkeld 1974 II: 206.

38 On the making of medicine men see Elkin 1977: 15-33, 53-54, 79-80. Elkin notes that in other south-eastern bands, medicine man obtained quartz crystals from a sky spirit in dreams.

39 Threlkeld, 'Second Half Yearly Report of the Aboriginal Mission Supported by the London Missionary Society ... June 21st, 1826', Threlkeld 1974 II: 206

40 On the meaning of the name see Threlkeld 1834b: 13. On the significance of the name change see Bennett 1969: 14. It should also be noted that in 1828 Threlkeld listed M'Gill's Aboriginal name as 'We-pohng' in his 'Return of the Black Natives belonging to Lake Macquarie and Newcastle', 21 May 1828, State Records of New South Wales [hereafter SRNSW], Colonial Secretary's In Letters [hereafter CSIL], 4/2045. The meaning of 'We-pohng' cannot be retrieved but it was possibly an age group term or a kinship name. On Aboriginal naming practices see Dixon 1980: 27-29. On totemism, see Berndt and Bernd 1964: 189-196; Stanner 1979: 106-143.

41 She is listed as 'M'Gill'"s wife in the 'Return of the Black Natives belonging to Lake Macquarie and Newcastle, 21 May 1828', SRNSW, CSIL, 4/2045. 
on the occasion of a general distribution of rugs, shirts, \&c. to the black natives' ${ }^{4}{ }^{42}$ Colonial officials, imposing their own conceptions of authority, listed him as a 'chief' in 'Native Returns' in 1828 and $1833^{43}$ and in 1830, Governor Darling presented him with a brass plate inscribed 'Barabahn, or MacGil, Chief of the Tribe at Bartabah, on Lake Macquarie; a Reward for his assistance in reducing his Native Tongue to a written Language'. ${ }^{44}$ Although the Awabakal would not have recognised him as such - traditional authority was exercised by male elders - it is highly likely that Biraban's work as a cross-cultural intermediary increased his influence in the band. ${ }^{45}$

During these early years, Biraban's translation work with Threlkeld informed - and was informed by - the development of their colonial and crosscultural relationship. While the award Biraban received from the governor quite possibly on Threlkeld's recommendation - was significant it notably cast him in the role of assistant. To a considerable extent this mirrored Threlkeld's own representation of Biraban's position. Although it was, in fact, primarily Biraban who instructed Threlkeld, carefully teaching him Awabakal words and phrases as they traveled, fished and talked, the missionary often tended to downplay Biraban's work. ${ }^{46}$ As Penny van Toorn has observed, Threlkeld was 'equivocal' about Biraban's role, describing him as 'my black tutor', or 'the valuable assistant in obtaining a knowledge of the language', but then claiming for himself the role of primary translator. ${ }^{47}$ This is strikingly evident in the title Threlkeld gave their first published work, printed in 1827: Specimens of a Dialect of the Aborigines of New South Wales; Being the First Attempt to Form Their Speech into a Written Language. In this title, Threlkeld privileges the work of writing, the communicative medium of the colonising society, over Biraban's efforts to teach him the Awabakal language; indeed the title implies that by transcribing Awabakal words he was transforming their speech into a language proper for the first time. As David Murray has observed, writing of a parallel colonial history, although it is the colonised who do most of the language-learning and

42 Threlkeld, 'Return of Black Natives in the district of Newcastle, 1829', SRNSW, CSIL, 4/2045.

43 In 1828 a police officer listed Biraban under the name 'M'Gill' as 'Chief' of the 'Coal River tribe', - Coal River being the alternate British name for the Hunter River. The 'usual place of Resort' of the 'Coal River tribe', the officer gave as 'The town of Newcastle'. See 'Return of the Black Natives in the district of Newcastle, 1828', SRNSW, CSIL, 4/2045. Threlkeld, better informed, listed Biraban as 'belonging to Lake Macquarie and Newcastle', in 1828, and named 'Jemmy Jackass' or 'We-rah-kah-tah' as 'King of the District', see 'Return of the Black Natives belonging to Lake Macquarie and Newcastle, 1828', SRNSW, CSIL, 4/ 2045. In 1833, a police officer again listed Biraban (McGill) as chief in the 'Nominal Return of Natives present at the issue of Blankets at Lake Macquarie ...', SRNSW, CSIL, 4/666B.3, but in 1835 and 1838 the title is given to 'King Ben' in 'Return of Aboriginal Natives, taken at Lake Macquarie on June, 1835', SRNSW, CSIL, 4/2285.3, and 'Return of the Aboriginal Natives, taken at Ebenezer Lake Macquarie on the 21st May 1838', SRNSW, CSIL, 4/1133.3.

44 See Gunson, 'Introduction', Threlkeld 1974 I: 6

45 On the role of headmen in south-eastern Aboriginal society see Howitt 1904: 295-326.

46 For Threlkeld's own account of his translation work with Biraban see 'Second Half Yearly Report of the Aboriginal Mission Supported by the London Missionary Society. L.E. Threlkeld Missionary to the Aborigines of New South Wales, Newcastle June 21, 1826', Threlkeld 1974 II: 208. Other Awabakal also assisted.

47 van Toorn 2006: 43-44; 'Reminiscences', Threlkeld 1974: 46, 51. 
translating in colonial situations, the colonisers typically repress full knowledge of their translation efforts in order to maintain 'an image of uncomplicated colonial dominance' ${ }^{48}$ Certainly, it could be argued that Threlkeld's Specimens, as an assertion of the missionary's authority as a grammarian to organise and categorise the language, worked to promote an image of colonial superiority and control. It is worth noting, too, that the text includes the translated dialogue fragment: 'man belonging-to speak' which is highly suggestive of Threlkeld's very colonial understanding of Biraban's relationship to him. ${ }^{49}$ And yet it was also the case that Threlkeld presented the text as proof that the Awabakal did, in fact, have a language and were, contra the views of the settler-colonial majority, capable of instruction, civilisation and salvation. ${ }^{50}$ And further, even though Threlkeld considered Biraban's efforts primarily as subordinate to that end, it is evident from the words and phrases in the text, and from Threlkeld's related unpublished notes, that through the process of translation Biraban and others were able to compel the missionary, on occasion, to orient himself toward their framework of meaning. ${ }^{51}$ It should be noted, though, that the Specimens did not include any references to religious topics. Possibly neither Threlkeld nor Biraban wished to discuss such matters in any depth until he felt confident the other would understand. Threlkeld, at least, stated that he did not wish to attempt 'to make known Salvation to the Aborigines in their own tongue' until he was 'competent' in the language and could 'argue with them as men'. ${ }^{52}$

Threlkeld's optimism about the prospects for future evangelical success among the Awabakal was, however, short-lived. In 1829 the LMS dismissed him on the grounds that his expenses had become extravagant. ${ }^{53}$ Although sympathetic supporters persuaded Governor Darling to grant him 1,000 acres on the northern side of the lake and a salary, the salary was 350 pounds less than he had previously received. ${ }^{54}$ With less funding, and more limited supplies, Threlkeld found it difficult to persuade the Awabakal to stay. ${ }^{55}$

The Awabakal, meanwhile, faced more serious threats. In the late 1820s and through the 1830s, outbreaks of epidemic disease took more lives. Threlkeld later

48 Murray 1991: 6.

49 'A dialogue fragment from the Specimens: Yan-te-bo kore ko-ba wean' which Threlkeld translated firstly as, 'Thus man belonging-to speak', and then, 'let it be thus, as a black man speaks' is suggestive of the missionary's view of his relationship with Biraban (Threlkeld 1827: 24).

50 Threlkeld 1974: 228. On this point see also Roberts 2008.

51 This is particularly evident in Biraban's efforts to explain Awabakal pronominal forms and conceptions of agency; in the language the Awabakal used to describe their relations to place - strikingly as a matter of being, rather than simply residing; and in their attempts to explain aspects of their material culture and cultural activities. For a full analysis of this text see Keary 2002: Ch 6.

52 Threlkeld 1827: iv.

53 See Gunson's account of his dismissal and the ensuing controversy in 'Introduction', Threlkeld 1974 I: $21-25$.

54 Threlkeld to Thomas Mitchell, 29 August 1829, Threlkeld 1974 II: 247.

55 He later reported that where once he had been able to employ up to sixty men at a time, the loss of the Society's support meant he was able to employ six at most. See 'Examination of the Rev. L. E. Threlkeld by the Committee on the Aborigines Question 21 September 1838', Threlkeld 1974 II: 271. 
estimated that at his first mission site, 'upwards of sixty Blacks lie mouldering in the dust, of whom many were destroyed by ... the epidemic of the time'.56 Colonisation exacerbated the impact of disease. European livestock destroyed indigenous plants and drove away game, compelling the Awabakal to seek food in Newcastle and at other settlements. The number of violent assaults against Aboriginal people, women in particular, increased.$^{57}$ Better than most, Threlkeld understood their desperate situation: 'their land is taken from them, their food destroyed and they are left to perish', ${ }^{58}$

The Aboriginal response to this onslaught varied. Most found themselves forced into deeper relations of dependence on the invading population. According to one colonial observer, 'Many of the ... Blacks now loiter about the larger towns, earning a scanty and precarious subsistence, chiefly by begging'.$^{59}$ Alcohol became another deadly attraction. However, some Aboriginal men responded with violence. In 1835 Threlkeld learned that the neighbouring tribes 'were on the way down here to kill all belonging to this district'. ${ }^{60}$ Although this large-scale attack did not materialise, smaller groups of young men did periodically assault settlers, taking food, guns, and other articles and, in some cases, killing. ${ }^{61}$

There is also evidence that under the impact of colonisation, the Awabakal social and cultural order was breaking down. Reports of young men dressed in European clothing attacking settlers suggest that young people were developing new forms of violence, possibly without the sanction of band elders. According to Threlkeld, the traditional practice of punishment also fell 'into desuetude' in the 1830s. ${ }^{62}$ And, most tellingly, James Backhouse, a Quaker who visited the mission in 1836, reported the 'abandonment of the practice of ornamenting themselves by cutting their flesh; [and] their ceasing to knock out a tooth, on their youths attaining to manhood'. ${ }^{63}$ Backhouse's companion, George Walker, attributed the end of initiation ceremonies to 'their intercourse with Europeans', but demoralisation and population loss, particularly the loss of knowledgeable elders, were no doubt important contributing factors. ${ }^{64}$ Biraban's initiation in 1826 was, in fact, the last Threlkeld recorded.

56 'Annual Report of Mission to the Aborigines New South Wales, 1837', Threlkeld 1974 I: 137

57 By 1841 ten land grants totalling several thousand acres had been issued by the New South Wales government for lands around Lake Macquarie. See Clouten 1967: 52-67. See also Jervis 1946. Threlkeld wrote of colonial sexual assaults of Aboriginal women in his report of 1837, noting that the 'usual consequences' were 'disease and death': 'Annual Report of Mission to the Aborigines New South Wales, 1837', Threlkeld 1974 I: 137.

58 Threlkeld to G Burder and WA Hankey, 4 September 1826, Threlkeld 1974 II: 213.

59 Backhouse, 'Journal', 28 April 1836, Mitchell Library, MS B731, Microfilm Reel CY 1698.

60 Threlkeld to Alexander M'Leay, 25 August 1835, Threlkeld 1974 II: 257.

61 For accounts of some of these attacks see 'Deposition of Adam Rainy, Police Office, Brisbane Water, March 25 1835', 'Deposition of George Howard Lawrence, Dec. 19th 1834, Lake Macquarie', 'Deposition of John Munnering, Brisbane Water, Dec. 15th 1834', SRNSW, Clerk of the Peace, Supreme Court Papers, T 162 (1835 Argyle to Campbellton).

62 Threlkeld 1850: 6.

63 Backhouse 1843: 383.

64 Walker, 'Journal', 2 May 1836, Mitchell Library, MS B715, CY Reel 464. 


\section{Translating religious knowledge}

It was in this deteriorating situation that Threlkeld and Biraban began the work of translating religious concepts. Together, they completed the Gospel of Luke in 1831, a set of 'Prayers for morning and evening service' in 1834, the Gospel of Mark in 1837, and two published texts: in 1834, an Australian Grammar and in 1836, An Australian Spelling Book that included a set of lessons derived from scriptural selections. In 1850, after Biraban's death, Threlkeld reprinted these lessons in his final study of the language of the Awabakal, Key to the Structure of the Aboriginal Language, and added a set of explanatory notes that further illuminate his conversations with Biraban. Although it is certainly the case that Threlkeld's organisation and editing of these works again worked to repress Biraban's role, in the phrases and vocabulary these texts contain there is plentiful evidence of Biraban's work as interpreter and translator of Threlkeld's words. Further, it is notable that the Grammar and the set of explanatory notes include both translations of Christian terms and comments on the ceremonies, sacred sites, and Ancestral Beings of the Awabakal. Clearly, the work of translation involved a two-way exchange, but in a colonial situation, it was not an exchange between equals. Each pursued the exchange from a different vantage point and with different interests.

As a colonial evangelist, Threlkeld, of course, assumed that he was in charge of the work of translation and that Biraban would serve him and his god's purposes. ${ }^{65}$ Like all evangelical Protestants, he believed it was solely through the 'Word of God' that the Holy Spirit effected saving grace: the translation of Scripture so that all peoples could have direct access to the Word in the vernacular was a fundamental missionary duty. The assumption underlying this belief was that 'God's Word' was a transcendent spiritual truth that existed prior to language but was also, as such, a truth that could be accessed through any language. As Aleida Assman has argued, 'the spiritual status of the gospel was the gold standard that permitted the use of native tongues as convertible currencies'. Any language could become a transparent vehicle for the transcendent 'Word of the God'. ${ }^{66}$ These assumptions about the translation and transmission of Scripture were further supported by the theory that all non-Christian peoples possessed an ancestral memory of their relationship to the Christian god and, however much their religious notions might have degenerated, there were certain universals the idea of a deity, the concept of the soul, the very notion of religion itself - that remained. ${ }^{67}$ Threlkeld's task, as he understood it, then, was simply to acquire a knowledge of the relevant indigenous words and use them to communicate

65 The following dialogue fragment appears in Threlkeld's Grammar: 'Kore ko ba wiyella bit tia; Man belonging speak thou me; Speak to me in the black's language.' Threlkeld 1834: 128. Threlkeld translated the sentence first literally and then in free form. We can assume that 'Man belonging' was a reference to Biraban.

66 Assman 1996: 89. On evangelical assumptions about the translation of Scripture see Comaroffs 1991: 214-217; Gilmour 2006: Ch 1.

67 Threlkeld's acceptance of the notion that a memory of the true God persisted among nonChristian peoples is evident, for example, in his comment that the Awabakal were not 'left without some instinctive feeling of dependence on the great "Unknown Being"': 'Reminiscences', 
Christian truths. Threlkeld initially sought a knowledge of Awabakal religious concepts only in hopes of finding equivalents for Christian terms or gaining an understanding of potential 'obstacles' to their evangelisation. ${ }^{68}$

Biraban, on the other hand, approached the translation of sacred matters as a cross-cultural go-between in a colonial world. For him, this work of translation opened up an arena for engaging with a British individual - and British colonial society - on new terms. As an initiated Awabakal man, he was interested in the acquisition of sacred knowledge. He evidently wanted to learn more about the missionary's traditions and he took the work of translating seriously. Threlkeld later recalled that Biraban 'went through [his texts] sentence by sentence, and word for word, while I explained to him carefully the meaning as we proceeded' ${ }^{69}$ But, as we shall see, Biraban was able to direct the translation of Christianity to his own purposes. Moreover, he did not see Christianity as an exclusive religious truth nor view the missionary as his superior in spiritual knowledge. At the same time as he learned about Christianity, it is evident that he tried to teach Threlkeld about the significance of Awabakal Beings and sites. In the face of the colonisation of his country and the demoralisation of his people, this was to defy a colonial order that insisted on the subordination of Aboriginal people and denied the existence of meaningful Aboriginal life-worlds.

As we shall see, neither Threlkeld nor Biraban was able to fully control the process of translation. Certainly, Threlkeld's claims to colonial mastery were complicated and modified as the work of translation turned into a cross-cultural dialogue about Awabakal Beings and sacred matters, and, at the same time, while Biraban was able to direct Threlkeld to use certain Awabakal terms, he was unable to control the missionary's transcription of his words. As the work of translation proceeded there was, to use the words of translation theorist Wolfgang Iser, 'a mutual conditioning of positions, relationships, and the space between them. The positions in play [did] not stay the same, the relationships [kept] changing, and the space between them [was] made operative according to prevailing needs' ${ }^{70}$

\section{Sacred Beings and cross-cultural exchange}

The translation of 'God' was a necessary starting point: in order to introduce Christianity Threlkeld had to name his deity. Initially, he thought that the Awabakal might possess a general term for 'deity' that he could use for his own purposes. In Raiatea, he recalled, the LMS missionaries had adopted the Tahitian

Threlkeld 1974 I: 62. On universalisms in nineteenth-century Protestant thought see Assman 1996. On nineteenth-century theories about religion see Tambiah 1990: Ch 1; Chidester 1996: Ch 3.

68 Tyerman and Bennet instructed Threlkeld to make himself 'familiar with [Awabakal] customs, superstitions, and habits' as by 'a knowledge of these, you will see what the principal difficulties opposing your success are', Tyerman and Bennet 1825.

69 Threlkeld 1892[1857]: 126.

70 Iser 1996: 296. 
term ' $a t u a$ ', in the belief that 'atua' 'unquestionably referr[ed] to deity'. ${ }^{71}$ As early as 1825 he thought he might have found a similar term when Biraban and some other young men told him that a figure called 'Koen' was the 'being who made the first man'. But Threlkeld also learned that Koen provided the bone the karakul used for tooth avulsion in initiations. He added cautiously, 'their precise idea of this spirit is not as yet ascertained' ${ }^{72}$ He then made no further notes on Koen, Koin, or Koun, as he later spelled the name, and Biraban offered him no more information, until one day, probably in the early 1830s, Threlkeld asked Biraban to whom he called in times of danger. Biraban answered 'Koun' and, on this occasion, he gave the missionary a fuller account. ${ }^{73}$ Threlkeld related - and rephrased - this account in his 1834 Grammar. As he presented it, Koun, had three names, Ko-in, Tip-pa-kál, and Pór-ráng, and he was

in appearance like a black; he resides in the thick brushes or jungles; he appears occasionally by day, but mostly at night. In general he precedes the coming of the natives from distant parts, when they assemble to celebrate certain mysteries, as knocking out the tooth in the mystic rite, or when performing some dance. He appears painted with pipe clay, and carries a fire-stick in his hand; but, generally, it is the doctors, a kind of Magicians, who alone perceive him, and to whom he says, 'Fear not, come and talk.' At other times he comes when the blacks are asleep, takes them up as an eagle does his prey, and carries them away. The shout of the surrounding party often occasion him to drop his burthen; otherwise, he conveys them to his fireplace in the bush, where close to the fire he carefully deposits his load. The person carried tries to cry out, but cannot feeling almost choked: at daylight, Ko-in disappears, and the black finds himself conveyed safely to his own fire-side $!^{74}$

This extended description of Koun and his powers was significant for both Threlkeld and Biraban but for different reasons. For Threlkeld, Biraban's explanation made it clear that 'Koun' could never serve as an equivalent for 'God', even though, as he later wrote, there was no other approximate 'word in the language but of [this] equivocal character' ${ }^{75}$ Although, as he understood it, their belief in Koun showed that the Awabakal were not 'without some instinctive feeling of dependence on the great 'Unknown Being', Koun was too human, too embodied to be considered god-like for Threlkeld's purposes. ${ }^{76}$ More importantly, he did not seem to possess any of the characteristics - omnipotence, transcendence, an interest in exercising his power for good - that the missionary attributed to his own deity. Threlkeld accordingly decided to introduce new words for god in his translations: Eloi, which was derived from the Hebrew

71 Threlkeld 1850: 75.

72 'London Missionary Society Aboriginal Mission, New South Wales, December 1825', Threlkeld 1974 II: 192.

73 For an account of this exchange see 'Reminiscences', Threlkeld 1974 I: 62.

74 Threlkeld 1834a: 80-81.

75 Threlkeld 1850: 51.

76 'Reminiscences', Threlkeld 1974 I: 62. 
Elohim, and Jehovah or Yehóa, as he transcribed it for Awabakal pronunciation. ${ }^{77}$ He rejected 'God' itself because, as he later told another missionary linguist, William Ridley, 'the Aborigines ... had become familiar with the word God in profane oaths'. ${ }^{78}$

For Biraban this explanation of Koun's powers was significant for other reasons. This was important sacred knowledge. Indeed, the fact that it took Biraban several years to tell Threlkeld about Koun suggests that he may have felt torn between a reluctance to impart such knowledge to the uninitiated English man and an interest in instructing him. Certainly, as the nineteenth-century anthropologist AW Howitt later noted, if it had been lawful Biraban could have told Threlkeld more about Koun and the 'mysteries' Awabakal men celebrated when called together by him. ${ }^{79}$ Although Threlkeld probably misunderstood much, clearly Biraban wanted him to understand that Koun was a powerful Being; that it was he who established the laws and ceremonies of initiation; and that access to him was restricted to initiated men, particularly the karakul. ${ }^{80}$ In fact, it is likely that Threlkeld's earlier understanding that the Awabakal believed that Koun 'made the first man' was a misunderstood reference to Koun's role as the giver of initiation law, that is, the 'maker of men' ${ }^{81}$

A number of factors may have influenced Biraban's decision to tell Threlkeld about Koun: an interest in asserting Koun's powers in response to Threlkeld's assertions about the powers of his god; a growing confidence in a man who had proven himself a defender of the Awabakal; and, perhaps, during a period of considerable flux in Awabakal life, a willingness to break with custom and speak of such matters to an outsider. Indeed, in the context of gendered relations of knowledge and power in Awabakal life, Biraban's decision to teach Threlkeld about Koun and the sacred lives of Awabakal men suggests an invitation to establish a more significant relationship with the missionary on Awabakal terms.

77 Threlkeld 1850: 51. He used Eloi in his 1836 scriptural selections, in his set of Prayers for Morning and Evening Service, and in his gospel translations. However, he used Jehovah in his Grammar (Threlkeld 1834b: 130) and probably in his preaching, judging from his records of Aboriginal responses to his efforts. His use of Hebrew words may have derived from an understanding that while all languages were supposed to be potential vehicles for the Word of God, Hebrew held a privileged position as the first language of God. On this view of Hebrew see Olender 1992.

78 Ridley 1873: 277.

79 Howitt 1904: 497.

80 A Howitt and, more latterly, AP Elkin, have suggested that Koun was another name for a 'skyhero' or 'All-Father' figure common to tribes throughout the south-east. Known by a variety of names, the more well-known of which were Baiami of the Wiradjuri and Daramalun of the southern coastal tribes, this figure was understood to have given people their laws, instituted male initiation rites and then gone to reside in the sky from where he visited the karakul on the occasion of particular ceremonies, particularly men's initiation ceremonies. See Howitt 1904: 496-500; Elkin 1977: 25, 79-81. Niel Gunson points out that while this generalised description of the sky culture hero corresponds with much of Biraban's account of Koun, Koun both looked like a man when he resided in the bush and like an eaglehawk when he flew in the sky. Moreover, he often seemed less powerful than his female counterpart, Tip-pa-kal-lé-un. 'Introduction', Threlkeld 1974 I: 1-3.

81 In anthropological literature initiation is still referred to as the business of 'making men'. 
At the very least, in adopting the role of Threlkeld's instructor, he was adding a new dimension to his relationship with the missionary and challenging the hierarchies that Threlkeld and other colonists otherwise sought to maintain.

As they continued the work of establishing names for the tripartite Christian deity, the dynamics of their relationship and the work of translation became more complex. In their attempt to translate 'Holy Spirit', Threlkeld and Biraban did find and agree on the use of two Awabakal words: 'Yirriyirri' to convey 'holy' and 'marai' to convey 'spirit', making 'Marai yirriyirri'. ${ }^{2}$ However, Threlkeld's later comments show that this translation was in no way straightforward. In the notes attached to his set of scriptural lessons, Threlkeld defined yirriyirri as 'Sacred, reverend, holy, not to be regarded but with awe', but then added that yirriyirri also described 'the place marked out for mystic rites ... not to be profaned by common use, hence holy' - in other words, an initiation site - and he observed, too, that a sacred messenger could be described as 'yirriyirri-lang, one who acts sacredly, one who is holy' ${ }^{83}$ Evidently, then, yirriyirri did not refer to a general quality of sacredness; rather, it referred to the specific sacredness of men's spiritual domain. A dialogue fragment in Threlkeld's 1834 Grammar makes this gendered meaning explicit: 'Why do not women go with the men? Because it is a sacred concern ... Yanoa yirriyirr ka ke. ${ }^{\prime 84}$

The use of yirriyirri to translate 'holy' highlights some of the conflicting intentions at work in Threlkeld and Biraban's cross-cultural dialogue. For Biraban, it would appear that this particular translation offered an opportunity to teach the missionary more about Awabakal men's sacred practices and, at the same time, manage the Awabakal interpretation of Christianity. In suggesting yirriyirri to translate holy, Biraban was effectively casting the Holy Spirit as a yirriyirri figure for Awabakal men. Threlkeld's use of yirriyirri, on the other hand, raises other questions. Clearly he was aware of the word's meaning but rather than introducing a term of his own - 'Holi' perhaps - he accepted yirriyirri. Indeed, he used it for all translations of 'holy' or 'sacred', in his Awabakal gospels. He even used it, perhaps at Biraban's prompting, to translate 'prayer' as 'Wi-ya-li ta Yir-ri-yir-ri' that is, loosely, 'speaking in a sacred way'. ${ }^{85}$ It would appear, then, that Threlkeld was willing to go along with Biraban's gendered representation of the Holy Spirit as a Being for men only. While he no doubt hoped to break down the word's exclusive meaning, perhaps he reasoned that the Christian deity was male and indeed, in many respects, a full knowledge of Christian sacred practice was restricted to men. Whatever the case, his acceptance of yirriyirri shows both a growing awareness of an Awabakal world of meaning and a recognition of the necessity of engaging with that world on less than certain terms.

The missionary's notes on the word marai as a translation for 'spirit' point to a similarly unstable engagement with Awabakal concepts. In English, of

82 Threlkeld 1850: 49.

83 Threlkeld 1850: 59.

84 Threlkeld 1834a: 129.

85 Threlkeld 1834b. 
course, 'spirit' refers to both supernatural figures and a non-corporeal, eternal component of the self. It appears that Biraban offered Threlkeld no general term for Ancestral Beings (although he discussed them at length), but he did teach the missionary about Awabakal conceptions of the self. Threlkeld recorded fragments of their exchanges. In his 1834 Grammar he wrote that marai meant 'the soul, the spirit', adding, 'the same as the wind, we cannot see him'; 86 in the explanatory notes attached to his scriptural selections he elaborated: 'Marai', is 'the spirit ... in opposition to corporeal substance ... and mamuya is a 'ghost'; $; 7$ and finally in a lexicon he later completed for his translation of Luke's Gospel in 1859 he defined marai as 'spirit, soul of a living being' whereas mamuya was the 'spirit of a dead person' ${ }^{88}$ These definitions clearly show that marai was not the same as the European 'spirit' or soul: marai was a noncorporeal component of the living not the dead self. Biraban might have added that it was through the marai that an individual made contact with supernatural beings: it was an individual's marai that left the body during sleep or ceremony, travelled to other realms, encountered Ancestral Beings such as Koun, and acquired knowledge. ${ }^{89}$

In suggesting marai, then, for Holy Spirit, Biraban was reconfiguring the missionary's Being in Awabakal terms and, in the process, quite possibly reconfiguring Awabakal understandings of the sacred. As there is no indication in Threlkeld's translations that marai was the term to be used only for men's living spiritual selves, one wonders what it might have meant to the Awabakal to conceive of a marai as yirriyirri, that is, exclusively male. The notion that a sacred being might possess a marai may also have been new. To introduce such ideas was to suggest other ways of understanding the spiritual realm. Threlkeld, for his part, may have thought that in Awabakal terms the Holy Spirit could be regarded as the marai of the Christian god, that is, the sacred unseen spirit of a living being, in this case, 'God'. But again one suspects that he must have been aware of the potential complications of the translation.

For both Biraban and Threlkeld, then, it is evident that the work of translating 'God' and 'Holy Spirit' opened up a new realm of cross-cultural exchange. There was, of course, no need to translate Jesus Christ; Threkleld simply inserted the name as 'Jesu Krist' in his Awabakal prayers and gospels. ${ }^{90}$ But at the same time as Threlkeld sought to introduce his deity to the Awabakal, Biraban asserted his role as the missionary's instructor in Awabakal sacred matters. Indeed, it was, perhaps, in response to Threlkeld's statements about his deity, that Biraban decided to teach him about other Awabakal Ancestral Beings and sacred sites. Threlkeld recorded abbreviated versions of Biraban's accounts in his 1834 Grammar. In a section labelled 'persons', he described Koun's wife, the variously named Tip-pa-kal-lé-un, Mail-kun, Bim-póin, as a Being who carried off 'the natives in a large bag beneath the earth' and speared children dead; the male Being

86 Threlkeld 1834a: 88.

87 Threlkeld 1850: 59.

88 Threlkeld 1892[1859]: 222-223.

89 Howitt 1904: 434-442.

90 See Threlkeld 1834b. 
Ko-yo-ró-wén who attacked at the night, skewered men 'with his cudgel' and then roasted and ate them; Ko-yo-ró-wén's wife, Kur-ri-wilban, who had 'a long horn on each shoulder growing upward' with which she impaled her victims; and Put-ti-kán who, Threlkeld related, was 'like a horse' but bounded 'like a kangaroo, the noise of which ... is as the report of a gun'.$^{91}$ In another section on 'places', Threlkeld recorded a description of Yi-rán-ná-lai where Biraban had once compelled him to be quiet lest he anger the Being who resided there. ${ }^{92} \mathrm{He}$ also included the story of Kur-rur-kur-rán, the place of petrified wood, formed when a large rock 'fell from the heavens and killed a number of blacks ... they being collected together in that spot by command of an immense Guana'; the story of Mul-lung-bu-la, the name of two upright rocks created when 'two women ... were transformed into rocks, in consequence of their being beaten to death by a Blackman'; and the story of Wau-wa-rán, the waterhole where the monster Wau-wai resided and threatened to kill those who disturbed him. ${ }^{93}$ In addition, he recorded the names of 33 other places and made notes on the animals, plants or minerals with which they were associated. It is likely that these, too, had a spiritual significance for the Awabakal. ${ }^{94}$

Threlkeld's record of Biraban's accounts can be considered from a variety of perspectives. For Biraban the telling of these stories was, in many respects, a powerful assertion of the persistence of an Awabakal sacred geography in the face of colonisation. In teaching Threlkeld about Ancestral Beings, the names of places, and the stories associated with them, Biraban was telling him parts of Awabakal 'Law journeys', journey stories that Heather Goodall has described as 'powerful dramas of ethical and emotional struggles, as well as physical conflicts, between the great protagonists of the creation stories' ${ }^{\prime}{ }^{5}$ Much, clearly, was lost or distorted in Biraban's efforts to communicate these stories, and in Threlkeld's rewriting of them, and the introduction of European elements such as the horn, the 'horse', and the sound of the 'gun', suggests either innovation or translation difficulties. Nevertheless, as accounts of Law journeys, these stories would have contained important information about the rules of Awabakal life, relations between people and places, and proper modes of behaving at sacred sites. ${ }^{96}$ For Biraban to tell Threlkeld these stories was to assert that the land around 'Lake Macquarie' was his people's country, and that it was country alive with the presence of Awabakal Ancestral Beings despite the British presence.

91 Threlkeld 1834a: 80-81.

92 Threlkeld 1834a: 85. Of Yi-rán-ná-lai, he later related that when he called out while walking beneath some rocks there, Biraban 'instantly beckoned me to be silent' and told him the 'tradition of the place': 'Reminiscences', Threlkeld 1974 I: 65.

93 Threlkeld 1834a: 83-85.

94 Threlkeld 1834a: 82-85.

95 Goodall 1996: 3.

96 On stories of Ancestral Beings as sources of knowledge about the foundation of Aboriginal social institutions see Stanner 1979: 28-30. It should be noted that the stories, as recorded by Threlkeld, contain some introduced elements: the horns on the shoulders of Kur-ri-wilban (prior to contact the Awabakal would not have seen horned animals); the description of Put-ti-kán being like 'horse' and making a sound like 'the report of a gun'. Possibly Biraban introduced these elements in his effort to explain matters to the missionary. Possibly the meaning of certain aspects of the stories was shifting in response to colonisation. 
It was also to reframe his relationship with the missionary as a relationship in Awabakal space, a space in which he controlled the terms of their exchanges. When Threlkeld questioned his stories, Biraban corrected him. As Threlkeld later wrote, 'to call into question the truthfulness of their tradition would at once rank you amongst the "Stupid fellows", as the Aborigines term all heterodox persons who ... do not hold the tradition of their fathers' ${ }^{\prime 97}$

Threlkeld's attitude toward Biraban's stories was complex. As a missionary he regarded and recorded these stories as evidence of Awabakal 'ignorance', examples of the very 'superstitions' he sought to displace. ${ }^{98}$ In his Grammar he dismissively characterised their Beings as 'imaginary' ${ }^{99}$ His emphasis on their violent, threatening nature to the neglect of other characteristics - Koun, after all, was the Being to whom Biraban called for assistance - suggests the influence of prevailing European colonial theories about the inferiority of 'savage religions': savages were motivated by irrational fears of evil spirits rather than the inspiring love of God and the Awabakal were surely savages. ${ }^{100}$ Indeed, as Threlkeld saw it, while the Awabakal had 'superstitions', they lacked the most basic components of religion proper; they had, he later wrote, 'no priesthood, no altar, no sacrifice, nor any religious service, strictly so called' ${ }^{101}$ Such a conception of religion did not allow for the possibility of a sacred life grounded in landforms created by Ancestral Beings and expressed in ceremonial reenactments.

And yet even as Threlkeld derided Awabakal stories, he recorded them, and however abbreviated and distorted his records were, it is evident that he listened to Biraban, attended to the pronunciation of names and gained some understanding of Awabakal spiritual life. ${ }^{102}$ In his relationship with Biraban, there were moments in which he had to orient himself, albeit in limited ways, in an Awabakal world: Biraban made him stay silent at Yi-rán-ná-lai; in conversation with the Awabakal he had to use their place names, and through such conversations he was made aware of an Awabakal sacred geography. Indeed, the very number of the place names he recorded attests to both the instruction he received from Biraban and others, and his willingness to pay attention. In subsequently writing about Awabakal Beings and places for a colonial audience, and labelling them as superstitious, Threlkeld was re-establishing colonial hierarchies but he was also indicating to his colonial readers that such matters were worthy of their attention. This was not insignificant. In a society in which

97 'Reminiscences', Threlkeld 1974 I: 64.

98 'London Missionary Society Aboriginal Mission, New South Wales, December 1825', Threlkeld 1974 I: 189, 194.

99 Threlkeld 1834a: 80-81.

100 For a discussion of missionary theories of religion in the nineteenth century see Chidester 1996: 75-92. On the definition of religion in the West see also Tambiah 1990: Chs 1 and 2; Asad 1993: Ch 1.

101 'Reminiscences', Threlkeld 1974 I: 62.

102 Christopher Herbert has noted a similar paradox in the texts of Threlkeld's missionary colleagues in the Pacific who produced detailed ethnographies of the very cultures they also described as depraved, even diabolical. Herbert, however, is more interested in exploring the contradictions embedded in the missionary's ethnographic texts than in the details of their crosscultural engagement with Polynesian peoples: Herbert 1991: Ch 3. 
many regarded Aboriginal people as barely human, Threlkeld's accounts of Awabakal Beings pointed to an Aboriginal realm of meaning whose very existence few colonists would have imagined.

\section{Defining, and redefining, the Christian deity}

Threlkeld's ambivalent attitude toward Awabakal cultural life persisted. Possibly in response to what he had learned about Awabakal Beings and places, he decided, in 1836, to produce a set of nine lessons about the Christian god and the nature of a proper relationship to him. These lessons, no doubt designed to complement the missionary's set of 'Prayers for Morning and Evening Service' and his translation of Luke's gospel, were composed of Biblical verses. They emphasised that the Christian god consisted of Father, Son and Holy Spirit, that he was the all-powerful creator, lord, judge and savior of all, and that a relationship with him required belief, worship and love. Biraban and Threlkeld translated the lessons and the missionary included them in his 1836 Spelling Book. Threlkeld then later added a series of explanatory notes that shed light on the translation of key terms in the lessons and the translated gospels and prayers. Many of the lessons, aimed at negating Awabakal conceptions of the sacred, had distinctly colonial overtones. However, it is evident from Threlkeld's notes that as he inquired after translations for terms to define his god, Biraban continued instructing him, compelling him to engage with the very world he sought to displace. And, to a considerable degree, Biraban continued to control the translation of the missionary's message.

Of all Threlkeld's theological assertions, the idea that the Christian god was the sole and supreme creator was the most colonial in its implications in that it was directly aimed at undermining Awabakal creation stories and their spiritual relationship to their Beings and their land. As Threlkeld later wrote, the Awabakal's 'reverence for Remarkable Places', ran counter to the true 'Spirit of Christianity'; they had to be shown that the Christian god was the only god and the creator of everything and that people should worship him in 'every place'. ${ }^{103}$ In other words, Awabakal attachments to particular places and Beings had to be broken; they had to be made to realise that it was the Christian god who created everything. Accordingly, for his lessons Threlkeld sought translations for: 'There is one God; and there is none other but he'; 'He hath made heaven, and earth, and the sea, and all that is in them'; and 'Know ye that the Lord he is God; it is he that hath made us, and not we ourselves' ${ }^{104}$ To translate the word 'create' Threlkeld adopted 'Uma', which he understood from Biraban to be an all-encompassing word meaning 'to make, to create, to cause power, to effect, to do' ${ }^{105}$

To convey the idea that his god was all-powerful, again an implicitly colonial assertion, Threlkeld sought translations for: 'with God all things are possible';

103 'Reminiscences', Threlkeld 1974 I: 63.

104 Threlkeld 1836: 13-14 (Mark xii 32; Acts iv 24; Psalms c 3).

105 Threkleld 1850: 55. 
'God is greater than our heart, and knoweth all things'; and, for the Lord's prayer, the last of his lessons, 'Thine is the power and the glory for ever.' ${ }^{106}$ For these phrases, Biraban gave him: 'Kaiyu' meaning 'able, powerful, might' to make Kaiyu-kan, 'one who is able'; Kaiwul meaning 'great' in a comparative sense; and, for 'power and glory for ever', 'killibinbin yanti katai' which, Threlkeld wrote, could be translated as 'bright-shining thus always'. ${ }^{107}$ With these translations Threlkeld's message became entangled with some distinctly Awabakal ideas about the sacred; particularly with his use of 'killibinbin,' ('brightness' or 'shining') to convey 'glory', for brightness, especially the brightness of fire, had a special significance for Awabakal men. ${ }^{108}$ Quite possibly Threlkeld understood this. From Biraban he had learned that initiated men received a small bright quartz stone called a 'Yar-ro' which 'mystically ... meant fire or water'; that sacred messengers, puntimai, always carried fire with them as a 'protection against the powers of darkness; ${ }^{\prime 109}$ and that when karakul visited the 'sky' they might have contact with fire. ${ }^{110}$ Biraban's suggestion of 'killibinbin yanti katai' or 'brightshining thus always', to convey 'power and glory', suggests, then, a particularly Awabakal interpretation of the Christian god's power. Threlkeld's awareness of this is suggested in his inclusion in his lessons of the verse 'For our God is a consuming fire' - a choice which is otherwise somewhat perplexing. ${ }^{111}$ It would seem, then, that even as Threlkeld ostensibly sought to assert the omnipotence of his deity and displace Awabakal traditions, he was willing to draw upon their conceptions of sacred power.

The other terms to define his deity for which Threlkeld required translations - lord, father, judge, saviour - raised other difficulties. In most cases, there were no exact equivalents; Biraban appears to have offered the missionary the most proximate words available. For 'lord', Threlkeld borrowed pirriwul, which he believed meant 'chief, lord, king', although it probably meant leader or headman as there was no indigenous concept of chief. ${ }^{112}$ For his lessons, Threlkeld used this to translate numerous verses emphasising his god's position as supreme 'lord', and quite possibly the Awabakal's experience of British governance and colonial attempts to make chiefs gave them an understanding of what the missionary sought to convey. To translate 'father', Threlkeld used 'Biyung-bai' which, he learned, was an 'address to a father or elderly person', rather than 'Bin-tun-kin', which referred specifically to a 'male parent'. ${ }^{113}$ In order to convey the idea of judge and judgment, Threlkeld chose nguraki which he understood to mean 'skilful, wise' or 'A wise person, an initiated one'. Most likely this term referred to tribal elders who, Threlkeld learned, settled 'the mode of satisfaction'

106 Threlkeld 1836: 14, 16 (Matthew xix 26; 1 John iii 20; Matthew v 13).

107 Threlkeld 1850: 55, 68. In his Grammar, he defined 'Kil-li-bín- bín' as 'To shine, to be bright, to be glorious', Threlkeld 1834a: 97.

108 Threlkeld 1892[1859]:215.

109 Threlkeld 1834a: 92, 93.

110 'London Missionary Society, Aboriginal Mission, New South Wales, December 1825', Threlkeld 1974 II: 192.

111 Threlkeld 1836: 13 (Heb. xii 29).

112 Threlkeld 1850: 47.

113 Threlkeld 1834a: 86, 1850: 53. 
when someone violated Awabakal law. ${ }^{114}$ And for 'saviour' Threlkeld and Biraban came up with 'Mirromullikan', which Threlkeld understood to mean 'he is for-to-be one who keeps with care', hence a Saviour. Threlkeld also noted that to 'express a deliverer would be mankillikan, one who takes hold of, but the evil must be expressed out of which the person is taken, or to be taken' - a note that points to a distinctly different realm of spiritual activities and Threlkeld's awareness of the difficulties of borrowing terms from that realm. ${ }^{115}$ Threlkeld did not use 'mankillikan'. On occasion, though, it appears that the two men agreed to be inventive. In order to convey the notion of taking care of, in order to translate 'The Lord is my Shepherd', for the lessons, they used 'Wirrilli', from 'Wirrilliko, for to wind up as a ball of string which the blacks do to their long fishing lines, and opossum fur cords, to take care of them, to preserve them' ${ }^{116}$ Clearly, in this case and for the other words Threlkeld used, Biraban's translations reframed the missionary's message in distinctly Awabakal terms. And again, it is evident that the work of translation offered Biraban an opportunity to teach Threlkeld about Awabakal social roles and relations.

Further lessons in Awabakal cultural categories followed from the translation of terms to describe the human relationship with the Christian deity. The translation of 'belief', for instance, appears to have led to a remarkable discussion of differences between European and Awabakal epistemologies. For Threlkeld, as for all Christian missionaries, belief was crucial: converts not only had to possess a knowledge of Christian doctrine, they had to demonstrate a profound sense of conviction. ${ }^{117}$ But, as Biraban appears to have explained, the Awabakal did not distinguish knowledge from belief; rather they differentiated ways of knowing according to the bodily sense involved and, in some cases, whether the object known was a person or a thing. As Threlkeld understood it: 'to know a person by sight is gi-milliko', but 'to know a thing by sight', 'na-killiko'; 'To know by touch was nu-mulliko'; while 'ngurrulliko', was 'to know, to perceive by the ear, to understand', or 'to hear, to obey'. ${ }^{118}$ Threlkeld selected ngurrulliko to translate both 'to know' and 'to believe', perhaps on the basis that belief followed not from seeing but from hearing God's Word. He also, tellingly, translated this as 'to hear, to obey'. ${ }^{119}$ In his lessons, Threlkeld used ngurrulliko to translate his central message: 'believe on the Lord Jesus Christ and thou shalt be saved' ${ }^{120}$

Lastly, in their efforts to translate terms to convey the more personal aspects of the human relationship with the Christian god, Threlkeld and Biraban appear to have engaged in an extensive exploration of Awabakal emotional vocabulary. This is evident from the word lists Threlkeld included in his Grammar and from his scriptural translations. In his Grammar, he included, 'Yi-mul-liliko - to make

114 Threlkeld 1850: 56; Threlkeld 1834a: 90, 98. On the role of tribal elders as adjudicators see Threlkeld to William Westbrook Burton, 2 March 1836, Threlkeld 1974 II: 258.

115 Threlkeld 1850: 59.

116 Threlkeld 1850: 57-58.

117 On the priority assigned to belief in modern Christianity see Asad 1993: 39-48.

118 Threlkeld 1850: 54.

119 Threlkeld 1850: 61.

120 Threlkeld 1836: 16 (Acts xvi 31). 
light, as fur is caused to lie lightly before the blacks twist it into a cord, ... to encourage, to cheer up', and 'Bur-kul-li-ko - to be light as a bird, to fly, to be convalescent'. ${ }^{121}$ The care with which Threkleld transcribed these definitions suggests a growing appreciation, on his part, for the cultural specificity and poetry of Awabakal emotional expression. For his scriptural translations and prayers, however, it appears that Threlkeld had to adopt and adapt Awabakal words for his own purposes. To translate 'worship' and 'praise', for instance, Threkleld and Biraban used 'Murrárág koiyelliela - to be good in manner; to worship' and 'Murrárág wiyelliko - to speak good; to praise'. ${ }^{122}$ To convey 'love' they chose the 'nearest' word, 'pitul', which, according to Threlkeld meant 'Joy, peace, gladness, happiness, love.'123 And for 'repentance', Threlkeld and Biraban borrowed 'Minki', which Threlkeld understood to mean 'any mental or moral feeling; the feeling of sympathy; sorrow; compassion; penitence; patience, repentance'124 - a sequence of definitions that suggests an attempt to infuse his own meaning into the word. All of these translations, products of a dialogue about feelings and mental states, indicate that despite the missionary's public denigration of Awabakal cultural life, he and Biraban occasionally reached surprising levels of cross-cultural understanding.

\section{Indigenous responses to Christianity}

During and after all of this work of translation both Threlkeld and Biraban went about disseminating a knowledge of Christianity among Aboriginal people. Threlkeld's method was to read from his translated texts. At first, he read to 'small parties of natives, sometimes in the open air, sometimes in my Barn'. ${ }^{125}$ Then, as Awabakal numbers declined, he broadened his efforts and began preaching to 'tribes at Port Stevens and its vicinities ... Hunter's river and its dependencies $\ldots$ and other contiguous tribes' ${ }^{126}$

Biraban's methods of communicating were, not surprisingly, rather different. He relied on the spoken, not the written, word and, significantly, he conveyed his knowledge of Christianity at the same time as he learned and communicated new Aboriginal songs. Threlkeld observed his activities in both capacities. In 1835, he reported that 'Several of the blacks belonging to this district headed by $\mathrm{M}^{\prime}$ gill are traveling to Windsor, Parramatta, and Sydney in order to teach other tribes a new song and dance which have lately been brought down from the regions beyond the Liverpool plains. ${ }^{\prime 27}$ And through the 1830s, Threlkeld's reports indicate that Biraban travelled far to communicate his knowledge of Christianity as well. In 1837 Threlkeld related that some Aboriginal people near

121 Threlkeld 1834a: 96, 104.

122 Threlkeld 1859: 226. In his earlier translations Threkleld transcribed this as 'murroróng'; see Threkleld 1836: 16.

123 Threlkeld 1850: 52.

124 Threlkeld 1859: 223; Threlkeld 1834a.

125 '4th Report, 1834', Threlkeld 1974 I: 120.

126 '7th Report, 1837', Threlkeld 1974 I: 135.

127 '5th Report, 1835', Threlkeld 1974 I: 123. 
the Hunter River recognised him as 'the person of whom $\mathrm{M}^{\prime}$ gill the Aborigine had spoken', and 'appeared to be apprised of my pursuits' ${ }^{128}$ And the following year he wrote that when he spoke to another group about 'Death, Judgment, and a Righteous God', they responded 'O yes! M'gill had informed them before!'129 From these and other encounters, Threlkeld concluded that the Christian knowledge which has been communicated to $\mathrm{M}^{\prime}$ gill and other Aborigines, has been the subject of discussion amongst the remnant of the tribes forty miles distant'. ${ }^{130}$ The fact that Biraban communicated the religious knowledge he had acquired from Threlkeld at the same time as he passed on the songs he received from other tribes suggests that he regarded both in the same light: as knowledge to be learned and transmitted for indigenous purposes.

The ways in which Aboriginal people responded to Christianity, whether they learned of it from Threlkeld or Biraban, seem to have varied. Threlkeld's records indicate that some rejected the Christian god outright; others developed new interpretations of their own traditions in opposition; while others including, most significantly, Biraban, reinterpreted the Christian deity within an indigenous framework. No one interpretation of Christianity dominated. In all cases, indigenous people were working within a world of shifting meanings as they tried to comprehend the new religion in the context of the traumatic changes wrought by invasion.

Threlkeld's accounts of responses to his preaching show that scepticism was common. Indeed, from an Awabakal perspective, it is likely that few of his claims made sense. For instance, given that most Awabakal Beings had spouses Threlkelds' representation of his god as a father, a Biyung-bai, with a son but no wife was perplexing. On at least one occasion the missionary was asked if his god 'had ... a wife?' 131 The Awabakal also questioned Threlkeld's insistence that his god was an all-powerful creator who made, ' $u m a^{\prime}$, everything. After preaching to one group 'respecting creation', he reported that a woman asked 'if Jehovah created the Moon as well as the Sun', and added that 'several enquired if the different descriptions of Kangaroos were all made by him?'132 On another occasion, an Awabakal boy, 'Billy Blue', told him 'he thought it was all gammon [lies] that master had told him about the Creation, for who was there who saw God create man!'133 Given the colonial implications of Threlkeld's assertions about his god's powers as the creator of the earth and all living things such responses are not surprising. For the Awabakal, the very forms of the land and the character of its creatures bore witness to the truth of their creation stories and the truth, therefore, of their relationship to their country. ${ }^{134}$

128 '7th Report, 1837', Threlkeld 1974 I: 135.

129 'Concluding Remarks, 1838', Threlkeld 1974 I: 140.

130 '8th Annual Report, 1838', Threlkeld 1974 I: 144.

131 '3rd Report, 1833', Threlkeld 1974 I: 118.

132 'Memoranda, June 1837', Threlkeld 1974 I: 134.

133 'The 6th Annual Report of the Mission to the Aborigines, Lake Macquarie for MDCCCXXXVI', Threlkeld 1974 I: 134.

134 I have also discussed the Indigenous response to Threlkeld's insistence that his god was the sole creator in Keary 2006. 
Alongside reports of Aboriginal responses to his preaching, Threlkeld also presented a number of accounts of his efforts to convert Aboriginal individuals facing death. For Threlkeld, death was the last hope for conversion and salvation. For Aboriginal people, on the other hand, death was becoming all too common as disease, starvation and violence wreaked their toll. As Threlkeld's accounts show, Aboriginal responses to Christianity were profoundly shaped by the trauma of this unprecedented mortality.

One of the most striking 'point of death' exchanges Threlkeld recorded involved an Aboriginal man known to the colonists as 'Mickey'. In 1835 Mickey was captured, tried and sentenced to death by the colonial authorities for the alleged rape of an English woman. Before his execution, Threlkeld visited him in gaol and endeavoured to 'instruct him in the knowledge of God our saviour'. Mickey, he wrote, responded by declaring that 'The Blacks had a much more powerful Being than the Whites had, who ... would if he were executed, put out the eyes of all the Whites, and smite them with total blindness!'135 This defiant declaration suggests the emergence of a pan-Aboriginal opposition to the colonists manifested in a view of competing spirit forces. Evidently, Mickey accepted the existence of the "Whites" Being but he clearly regarded him as the Being of the colonists only. His assertion that the 'Blacks' collectively had a more powerful Being capable of blinding all the 'Whites' points to the development of an intertribal resistance movement that looked to an indigenous Being whose powers mirrored the great power, Kaiyu, that the whites attributed to their god. His declaration also most surely reflected a desire to return upon the whites the devastation they had inflicted upon Aboriginal people. This interpretation of colonial conflicts in spiritual terms - and attribution of new powers to an indigenous Being - suggests considerable cultural innovation in response to colonisation. Although we cannot know how widespread this idea of an allpowerful indigenous Being was, it is worth noting that in the same year Mickey issued his threat, Aboriginal people warned Threlkeld about the possibility of a large-scale attack against the whites. ${ }^{136}$ Evidently, collective hopes and plans for the destruction of the colonial population were circulating during this period. Mickey's threat suggests that for many such hopes had a spiritual dimension. ${ }^{137}$

In another 'point of death' exchange recorded by Threlkeld an Aboriginal man named 'Charley' offered a very different interpretation of Christianity in the face of colonisation. Charley had been deputed by his elders to kill an English man who had taken an Aboriginal woman and then transgressed tribal law by obtaining and opening an initiated man's 'Mur-ra-mai', or sacred 'talisman', as Threlkeld put it, in the woman's presence. ${ }^{138}$ The colonial authorities subsequently arrested, tried and sentenced Charley to death. Again the missionary visited and

135 '5th Report, 1835', Threlkeld 1974 I: 121-122.

136 Threlkeld to Alexander M'Leay, 25 August 1835, Threlkeld 1974 II: 257.

137 For an interesting discussion of an indigenous nativist movement among the Wiradjuri at this time see Carey and Roberts 2002.

138 See Threlkeld's description of the 'Mur-ra-mai' and the law against Aboriginal women seeing it in Threlkeld 1834a: 88-89. 
encouraged Charley to 'believe in and pray to Jesus Christ' and taught him some 'suitable prayers in his own tongue'. According to Threlkeld, after several days praying Charley asked 'Jesus to cast away all his evil deeds and to receive his soul when the whites kill his body.' Then, on the morning of his execution, he asked: 'When I am dead, shall I make good houses and be like the Whites in the other world?' At the gallows, he stood and repeated the prayer Threlkeld had taught him - 'Lord Jesus receive my spirit' - before the executioner let the trapdoor fall. ${ }^{139}$

From Threlkeld's perspective, Charley's apparent acceptance of Christ could be counted a success. The meaning of this acceptance, though, is open to question. Charley's interest in whether he would make houses and 'be like the Whites in the other world', - (as a mamuya?) - indicates not faith in Christ but a very different interpretation of the missionary's message. Unlike Mickey, Charley was not interested in the destruction of the white population; rather he appears to have hoped to become like the whites, or at least acquire their material assets. Tony Swain and Barry McDonald have suggested that this idea that Aboriginal people would become like whites, 'jump-up whitefeller' after death, was a product of a cosmological shift as Aboriginal people sought to accommodate the colonists in a new moral order. They argue that as an indigenous 'locative cosmology' gave way under the impact of colonisation to a cosmology focused on temporality and the future, becoming 'like whites' after death was a way of making sense of the colonial presence and an indigenous future. ${ }^{140}$ Certainly Charley's question shows that this idea was circulating in the 1830s, although it was clearly one response among many. His particular situation - isolated from his people and awaiting execution by the 'Whites' for following customary law - also tells us something about the trauma that might have induced such a shift.

In the context of these widely varying responses to the new Christian deity, it is notable that some Awabakal did come to view this deity as a living presence in their lives. References to Awabakal regard for the Christian god are scattered throughout Threlkeld's texts. For example, when he told an Awabakal man who had sworn a 'dreadful' oath, 'that such language provoked God', he reported that the man later asked him, "whether he who is above was still angry with him for the expression he had used?' ${ }^{\prime 41}$ On another occasion, he related overhearing an Awabakal boy correcting another who had sworn: 'Do not say those words, they are bad ... for he who is above is angry with those who use them.' ${ }^{142}$ Other Awabakal appear to have been concerned about the consequences of uttering the Christian god's name. Threlkeld wrote about one boy who, when 'asked if he knew who was the Saviour?' replied, 'Yes', but when asked what his name was answered that 'he did not like to mention it, because it was sacred'. He

139 '5th Report, 1835', Threlkeld 1974 I: 122.

140 Barry McDonald discusses this idea in his analysis of New England corroboree songs from the 1840s. Unlike Swain, however, McDonald argues, as I do, that this shift was only one response to contact among others: Swain 1993: Ch 3; McDonald 1996.

141 '3rd Report, 1833', Threlkeld 1974 I: 118.

142 '9th Report, 1839', Threlkeld 1974 I: 159-160. 
noted that this was not a 'solitary instance' and that he had observed 'a similar feeling in others'. ${ }^{143}$ The Quakers who visited in 1836 also observed of some of the Awabakal that: 'when allusion is made to a Supreme Being, ... their countenances immediately assume an air of seriousness [and] they cast their eyes to the ground'. ${ }^{144}$

In all of these accounts it is notable that the Awabakal expressed their regard for the Christian deity in relation to matters of speech - and that they were all men or boys. While it is possible that the missionary's emphasis on the power of the Word may have led some to think that this was his god's particular concern, it seems more likely that they were responding to Biraban's representation of Christianity as a sacred - yirriyirri - knowledge for initiated men. Rules regulating speech governed the behavior of initiated men in Awabakal society: sacred matters were to be spoken of with care, in certain circumstances, and only with qualified individuals. ${ }^{145}$ Threlkeld and Biraban's translation of prayer as 'Wi-ya-li ta Yir-ri-yir-ri' or 'Speaking in a sacred way', could only have reinforced such a notion. ${ }^{146}$ The boy's refusal to say the name of Christ was, then, more likely a way of claiming knowledge in accordance with Awabakal codes of conduct rather than a sign that Threlkeld's preaching was having the effect he intended.

While these examples are suggestive of Biraban's role in translating and transmitting a knowledge of Christianity to Aboriginal people there are, unfortunately, only a few clues as to exactly how he portrayed the new religion and its deity. However, one piece of evidence, a dream narrative Biraban recounted to Threlkeld in 1836, offers some revealing insights. It is also the strongest evidence that Biraban did, in fact, represent a knowledge of the Christian god as a yirriyirri knowledge for men. Threlkeld was so struck by the dream that he reported Biraban's account in full:

The night before last, when coming hither, I slept on the other side of the Lake, I dreamed that I and my party of blacks were up in the Heavens; that we stood on a cloud; I looked round about in the Heavens; I said to the men that were with me, there He is? there is He who is called Jehovah; here he comes flying like fire with a great shining - this is He about whom the whites speak. He appeared to me like a man with clothing of fire, red like a flame. His arms were stretched out like the wings of a bird in the act of flying. He did not speak to us, but only looked earnestly at us as he was flying past. I said to the blacks with me, let us go down, lest he take us away; we descended on the top of a very high mountain ... we came to the bottom, and just as we reached the level ground, I awoke. We often dream of this mountain, many blacks fancy themselves on the top when asleep. ${ }^{147}$

143 '10th Annual Report, 1840', Threlkeld 1974 I: 166.

144 Backhouse, 'Journal', 30 April 1836, Mitchell Library, MS B731, Microfilm Reel CY 1698.

145 On speech prohibitions, particularly against saying the name of the 'sky hero' figure see Blows 1995: 57-58; also Howitt 1904: 236.

146 Threlkeld $1834 \mathrm{~b}$.

147 '6th Annual Report of the Mission to the Aborigines, 1836', Threlkeld 1974 I: 134. 
Although Threlkeld clearly rewrote and rephrased Biraban's narrative, his report nevertheless provides much valuable information. The first point to be emphasised is that Biraban encountered Jehovah in a dream. Throughout the indigenous south-east dreams were the realm of encounters with the supernatural: through dreams, an individual's marai travelled to other realms, acquired religious knowledge, and channelled supernatural power. Dreams enabled cultural innovation: Ancestral Beings revealed new songs to people in dreams. ${ }^{148}$ For Biraban, then, to dream of an encounter with a supernatural being including, and perhaps especially, a being 'about whom the whites speak', was both to demonstrate an unusual spiritual power and introduce new religious knowledge in a recognised and legitimate manner. Such a dream would have enhanced his role as a messenger of Christianity by grounding his authority to speak, not in the missionary's book, but in an indigenous form of experiencing the sacred.

The second point to be made is that the Jehovah of Biraban's dream bears a striking resemblance to Koun, the powerful law-giver of initiated men. Penny van Toorn, in her analysis of this dream narrative, has suggested that Biraban was influenced by Biblical images of winged spirits and that he envisioned Jehovah as the south-eastern 'sky-god' Baiami, but this interpretation ignores the evidence of Biraban's translation work and his description of Koun. ${ }^{149}$ Like Koun, Biraban's Jehovah is a male being who visits Awabakal men in their sleep, flies in the sky, is associated with fire (Koun carried a firestick), and threatens to carry men away. This Jehovah is most definitely not the father, judge or lord of all from Threlkeld's teachings but a distinctly indigenous being, who, it seems, appeared only to men. It is possible that certain parallels between Threlkeld's stories about Jehovah and Awabakal understandings of Koun suggested themselves to Biraban. For instance, Threlkeld's claim that his god resided in 'moroko', 'the sky', corresponded with an Awabakal understanding that the sky was, at times, the realm of Koun. ${ }^{150}$ Also, Jehovah's appearance as being 'like fire with a great shining' and 'dressed in clothes of fire' recalls Biraban's translation of 'power and glory' in the Lord's Prayer as 'killibinbin yanti katai' or 'brightshining thus always'. But for the most part, even though this Jehovah is referred to as 'He about whom the whites speak', his fiery appearance, flying in the sky, is indigenous in form and character. In short, it appears that Biraban remade the Christian deity as an indigenous being, incorporating him into a distinctly Awabakal cosmological order, and portrayed him as a special yirryirri figure for Awabakal men.

148 On the function of dreams in Aboriginal spiritual life see Howitt 1904: 434-442. Elkin notes that individuals went up into the sky in a dream as part of the process of becoming a medicine man: Elkin 1977: 80, 86-88. On dream travel as a cultural phenomenon see Lohmann 'Introduction', Lohmann 2003: 1-18.

149 van Toorn 2006: 47-52. It should also be noted that there is no record of Biraban mentioning Baiami in Threlkeld's writings. On the question of the relationship between Koun and Baiami see footnote 80 .

150 Threlkeld 1850: 56. On the sky as a sacred realm see Berndt and Berndt 1964: 413. 
A third point to be made is that Biraban's mention of the mountain he descended in the dream and his statement, rephrased by Threlkeld, that 'many blacks fancy themselves on the top [of the mountain] when asleep', situates his encounter with Jehovah in an Awabakal sacred geography. Threlkeld observed that the Awabakal distinguished 'high places' as 'sacred', and he reported that on a high hill he had once found 'a circular erection of stones, of about 5 or 6 feet diameter, and two or three feet high'. Biraban informed him 'that the tradition was, that the Eagle-Hawks brought these stones and placed them together in the form in which they were found'. ${ }^{151}$ Possibly, given the fact that Biraban's own name meant eaglehawk, he had a personal totemic association with the mountain. ${ }^{152}$ It should also be noted that Koun, who took men like 'an eagle does his prey', according to Biraban, was strongly associated with this bird. Jehovah's appearance in Biraban's dream like a 'bird in the act of flying' and Biraban's descent from the mountain resonates with associations to these elements of Awabakal men's sacred lives. Although the connections remain obscure, what is clear is that Biraban's encounter with Jehovah took place in Awabakal terms and in an Awabakal country still alive with spiritual significance. ${ }^{153}$

However, there is an ambiguity in Biraban's dream narrative that should be noted. In most Awabakal dream encounters Beings speak. As related by Threlkeld, Koun, for example, introduced himself to karakul by saying 'Fear not, come and talk.' ${ }^{\prime 54}$ Given that the Awabakal learned from spirit beings through hearing - 'ngurrulliko' - Biraban's report that Jehovah did not speak but rather 'looked earnestly' at the party as he flew by is significant. It suggests that while Jehovah, the powerful Being of 'whom the whites speak', might make himself manifest to Biraban and his men, they were not, or perhaps not as yet, to be granted full access to a knowledge of his powers.

Considered in the broader context of colonialism, Biraban's dream narrative is evidence of an innovative response to Christianity. Unlike Mickey, Biraban did not reject the Christian god, the whites' Being, as a force to be opposed; nor, like Charley did he view this Being as a figure who would preside over his transformation into a white person in the after-life. But nor, significantly, did he accept the Christian deity as Threlkeld presented him: the Jehovah Biraban encountered was not an all-powerful creator, lord, judge, father, or saviour; and Biraban did not conceive of his relationship to him as a personal relationship expressed in terms of belief, worship, repentance and love. Rather, in refiguring Jehovah as an indigenous Being, Biraban was acting in a fashion consistent with his activities as a translator, cross-cultural go-between and defender of indigenous

151 'Reminiscences', Threlkeld 1974 I: 65-66.

152 Stanner observed that totems were often associated with places marked by striking physical features, including mountains: Stanner 1979: 134.

153 van Toorn has suggested that Biraban's vision of Jehovah as 'Biami in the form of Eaglehawk' was part of a post-colonial reinterpretation of south-eastern indigenous traditions in which the eaglehawk figure represented the whites who stole children. This is an interesting interpretation but again it ignores Biraban's description of Koun and Koun's relationship with initiated men. See van Toorn 2006: Ch 2.

154 Threlkeld 1834a: 80. 
sacred life: he was incorporating the colonists' deity into an indigenous cosmology without conceding authority to the colonial order. One might further speculate that in the context of the breakdown of the Awabakal social and cultural order the end of initiation ceremonies, the reduction of hunting opportunities and the colonists' attacks on Awabakal women - Biraban's vision represented an effort to transform the colonists' deity into a new source of power and knowledge for Awabakal men. Certainly, Biraban's vision provided another opportunity to cast himself as a leader at a time when elders were dying and traditional forms of authority were failing. By the late 1830s it is clear that Biraban had established a position for himself as a leader and visionary. In 1839 a visitor to the mission station, the American naval explorer, Charles Wilkes, reported that Biraban was 'always a leader in the corrobories and other assemblies'. ${ }^{155}$

For Threlkeld, on the other hand, Biraban's dream was evidence that his message was having some effect, but it was certainly not the conversion he hoped for. Indeed he later wrote despairingly that 'although [Biraban] is better informed [about Christian doctrine] than any of the natives with whom I am acquainted', he doubted 'whether any moral or religious impression has been made upon him'. ${ }^{156}$ Nevertheless, it is notable that while rejecting Biraban's indigenous interpretation of Jehovah, there are indications that during the 1830s Threlkeld became open to the idea that Aboriginal people might at least have their own ways of transmitting, if not understanding, Christianity. In 1835 he expressed the hope that Aboriginal messengers like Biraban might become messengers for Christianity: 'the same custom which promulgates the new Song will convey throughout Australia, "The glad tidings of a Saviour Christ the Lord"'. ${ }^{157}$ Given the prevailing climate of colonial contempt for Aboriginal people, Threlkeld's vision of indigenous messengers, the sacred or yirriyirri puntimai, communicating Christianity across the country stands as a remarkable expression of appreciation for the institutions of Aboriginal cultural life.

\section{Conclusion}

Threlkeld's mission closed in December 1841 after the colonial government withdrew its support. Disease and dispossession had devastated the Awabakal. In 1840, Threlkeld counted only 16 in his annual return. ${ }^{158}$ In the face of such catastrophic loss, Biraban himself succumbed to alcoholism and passed away shortly afterwards. Years later, Threlkeld remembered him as his 'almost daily

155 Wilkes 1845: 269.

156 'Examination of the Rev. L. E. Threlkeld by the Committee on the Aborigines Question, 21 September, 1838', Threlkeld 1974 II: 271.

157 '5th Report 1835', Threlkeld 1974 I: 123.

158 'Return of the Aboriginal Natives, taken at Lake Macquarie on 1st May 1840', SRNSW, CSIL, 4560 . 
companion for many years' acknowledging that he was 'principally indebted [to his intelligence] for much of [his] knowledge respecting the structure of the language'. ${ }^{159}$

In his final years, while serving as a chaplain in Sydney, Threlkeld returned to his study of the language of the Awabakal and produced his most ambitious work, Key to the Structure of the Aboriginal Language, in $1850 .{ }^{160}$ In it he sought to demonstrate the philologist Max Muller's theory that 'every sound forms a root'; and that each letter was a 'visibleroot ... conveying an abstract idea of certain governing powers which are essential' ${ }^{161}$ With this theory, Threlkeld analysed a series of words, including, most notably, 'Koun'. The letters 'K-O-U-N', he contended, conveyed 'Being, purpose, power, and presentiality', an analysis that suggests a continuing fascination with Koun and, perhaps, a lingering suspicion that this Being represented a remnant understanding of the 'true' god. ${ }^{162}$

Threlkeld's Key can be read from a variety of perspectives - as a contribution to philological studies, a defence of the integrity of the Awabakal language, or as a curious piece of colonial literature. But, it is, perhaps, most interesting to consider Threlkeld's final analysis of the language of the Awabakal in relation to Biraban's interpretation of Christianity for, in a sense, each man turned his knowledge of the other's culture into a claim for authority in his own. While Biraban used his interpretation of Christianity and his vision of an indigenous Jehovah to cast himself an Awabakal spiritual leader, Threlkeld used his knowledge of the Awabakal language to claim the authority of the European natural scientist. With the Key Threlkeld recast the translation work that had failed to produce success in the mission field as a gain for colonial science. In 1851 he sent his study to the Royal National Exhibition in London and in 1854 he was rewarded with membership of the Ethnological Society. ${ }^{163}$ For both Threlkeld and Biraban, then, the work of translation created new sources of authority. But in the context of colonial relations there were also significant differences between their approaches. Biraban, acting in his position as go-between, appears to have sought to accommodate the colonial presence by refiguring and incorporating the Christian deity as a living force in an Awabakal world. Threlkeld, on the other hand, used his skills and his position in colonial society to turn the living linguistic and cultural world of the Awabakal into an object for philological study. ${ }^{164}$ In the Key, the structures of philological analysis, the letter-by-letter breakdown of Awabakal words for the purpose of proving a European theory, work to obscure the dynamism of Threlkeld's original cross-cultural exchanges with Biraban and naturalise an image of colonial dominance.

159 Threlkeld 1850: 5.

160 On Biraban's final years see Gunson's account in Threlkeld 1974 II: 317. On the last years of the mission see Gunson, 'Introduction', Threlkeld 1974 I: 28-29; Clouten 1967: 93-97.

161 Threlkeld 1850: 9.

162 Threlkeld 1850: 29.

163 Richard Cull to Threlkeld, 31 July 1854, Threlkeld 1974 II: 298.

164 Threlkeld 1850: 9; Richard Cull to Threlkeld, 31 July 1854, Threlkeld 1974 II: 298. 
For Threlkeld, then, the work of translation that he had first pursued as part of a project of colonial transformation ended up as material for the production of colonial knowledge. But this work was always and unavoidably, a crosscultural activity and Threlkeld's texts were necessarily dialogic productions. Preserved in the fragments of speech in his linguistic texts and in the records of his exchanges with Biraban and other Awabakal, there are traces of a counterhistory of translation and cultural innovation that show how the Awabakal confronted, interpreted, and even used Christianity in their attempts to deal with the traumatic changes wrought by colonisation.

\section{References}

\section{Primary sources}

Backhouse, James 1835-6, 'Journal', Mitchell Library, Sydney, MS B731, Microfilm Reel CY 1698.

- 1843, Narrative of a Visit to the Australian Colonies, Hamilton, Adams, and Co, London.

Brisbane, Governor Thomas 1825, 'Deed of trust to Aboriginal Mission by Sir Thomas Brisbane', Historical Records of Australia, series I, vol XI: 512-513.

Dangar, Henry 1828, Index and Directory to Map of the Country Bordering upon the River Hunter; the Lands of the Australian-Agricultural Company; with the Groundplan and Allotments of King's Town, New South Wales, etc., Joseph Cross, London.

Darling, Ralph, Governor 1826, 'Dispatches, September 1826', Mitchell Library, A 1197, Reel CY 522.

London Missionary Society 1824, Reports of the London Missionary Society: the report of the Directors to the Thirtieth Annual Meeting of the Missionary Society, General Meeting of the LMS, London.

- 1825, Reports of the London Missionary Society: the report of the Directors to the Thirty-First Annual Meeting of the Missionary Society, General Meeting of the LMS, London.

- 1829, Quarterly Chronicle of Transactions of the London Missionary Society in the Years, 1824, 1825, 1826, 1827, and 1828, vol III, printed for the Society by J Dennett, London.

Menzies, Lieutenant Charles 1804, 'Reports', Historical Records of Australia, series I, vol V: 6, 113, 423. 
New South Wales. Colonial Secretary, 'Return of the Black Natives belonging to Lake Macquarie and Newcastle', (Threlkeld) 21 May 1828, State Records of New South Wales, Sydney [hereafter SRNSW], Colonial Secretary's In Letters [hereafter CSIL], 4/2045.

- 'Return of the Black Natives in the district of Newcastle, 1828', SRNSW, CSIL, $4 / 2045$.

- 'Return of Black Natives in the district of Newcastle, 1829', SRNSW, CSIL, 4/2045.

- 'Nominal Return of Natives present at the issue of Blankets at Lake Macquarie and names of those absent', SRNSW, CSIL, 4/666B.3.

- 'Return of Aboriginal Natives, taken at Lake Macquarie on June, 1835', SRNSW, CSIL, 4/2285.3.

- 'Return of the Aboriginal Natives, taken at Ebenezer Lake Macquarie on the $21^{\text {st }}$ May $1838^{\prime}$, SRNSW, CSIL, 4/1133.3.

- 'Return of the Aboriginal Natives, taken at Lake Macquarie on 1st May 1840', SRNSW, CSIL, 4560.

Ridley, William 1873, 'Australian languages and traditions, II', The Journal of the Anthropological Institute of Great Britain and Ireland 2: 275-291.

Threlkeld, LE 'Answers at his ordination in London in 1815', Mitchell Library, London Missionary Society 'South Sea Mission' papers c1800-1915, A 381, Reel CY 877.

- c1827, Specimens of a Dialect of the Aborigines of New South Wales; being the First Attempt to Form Their Speech into a Written Language, printed at the 'Monitor Office' by Arthur Hill, Sydney, New South Wales.

- 1834a, 'A Selection of Prayers for the Morning and Evening from the Service of the Church of England. Intended for the introduction of publick worship amongst the Aborigines of Australia by the Venerable W. G. Broughton M. A., Archdeacon of New South Wales and its Dependencies. Translated into the Northumberland Dialect', Mitchell Library, ML ZA 1446, Reel CY 2214.

- 1834b, An Australian Grammar Comprehending the Principles and Natural Rules of the Language, as Spoken by the Aborigines in the Vicinity of Hunter's River, Lake Macquarie Ec. New South Wales, Stephens and Stokes, Sydney.

- 1836, An Australian Spelling Book in the Language as Spoken by Aborigines in the Vicinity of Hunter's River, Lake Macquarie, New South Wales, Stephens and Stokes, Sydney. 
- 1850, A Key to the Structure of the Aboriginal Language; Being an analysis of the particles used as affixes, to form the various modifications of the verbs; shewing the essential powers, abstract roots, and other peculiarities of the language spoken by the Aborigines in the vicinity of Hunter River, Lake Macquarie, etc., New South Wales; together with a comparison of Polynesian and Other Dialects, Kemp and Fairfax, Sydney.

- 1892[1857], 'Gospel of Saint Luke', reprinted in LE Threlkeld 1892, An Australian Language as Spoken by the Awabakal, John Fraser (ed), Charles Potter, Government Printer, Sydney: 124-194.

- 1892[1859], 'Lexicon to the Gospel According to Saint Luke', reprinted in LE Threlkeld 1892, An Australian Language as Spoken by the Awabakal, John Fraser (ed), Charles Potter, Government Printer, Sydney: 201-227.

- 1892, An Australian Language as Spoken by the Awabakal, the People of Lake Macquarie, being an account of their language, traditions, and customs, John Fraser (ed), Charles Potter, Government Printer, Sydney.

- 1974, Australian Reminiscences and papers of L. E. Threlkeld, missionary to the Aborigines, 1824-1859, 2 vols, Niel Gunson (ed), Australian Institute of Aboriginal Studies, Canberra.

- and John Williams (with Tamatoa) 1822, 'Raiatea', Evangelical Magazine and Missionary Chronicle 30: 75-77.

Tyerman, Daniel and George Bennet 1825, 'Instructions' in London Missionary Society and Aboriginal Reserve at Lake Macquarie, 1825-45 Papers, SRNSW, SZ 1000.

- 1832, Journal of Voyages and Travels (Deputed from the London Missionary Society to visit their various stations in the South Sea Islands, China and India, Ec., between the years 1821 and 1829, compiled from the original documents by James Montgomery, in three volumes), vol II, Crocker and Brewster, Boston.

Walker, George Washington 1836, Journal, Mitchell Library, MS B715, CY Reel 464.

Wilkes, Charles 1845, Narrative of the United States Exploring Expedition, during the years 1838, 1839, 1840, 1841, 1842, Vol II, C. Sherman, Philadelphia.

\section{Secondary sources}

Asad, Talal 1993, Genealogies of Religion: Discipline and Reasons of Power in Christianity and Islam, The Johns Hopkins University Press, Baltimore and London. 
Assman, Aleida 1996, 'The curse and blessing of Babel; or, looking back on universalisms', in The Translatability of Cultures: Figurations of the Space Between, Sanford Budick and Wolfgang Iser (eds), Stanford University Press, Stanford.

Austin, Kellie et al 1995, Land of Awabakal, Yarnteen Aboriginal and Torres Strait Islander Corporation, Hamilton, NSW.

Austin-Broos, Diane 1994, 'Narratives of the encounter at Ntaria', Oceania 65: 131-150.

Bennet, FC 1969, The Story of the Aboriginal People of the Central Coast of New South Wales, Brisbane Water Historical Society, Wyong NSW.

Berndt, Ronald and Catherine Berndt 1964, The World of the First Australians: An Introduction to the Traditional Life of the Australian Aborigines, University of Chicago Press, Chicago.

Blows, Johanna M 1995, Eagle and Crow: An Exploration of an Australian Aboriginal Myth, Garland Publishing, New York and London.

Brayshaw, Helen 1986, Aborigines of the Hunter Valley: A Study of the Colonial Records, Scone and Upper Hunter Historical Society, Scone, New South Wales.

Brock, Peggy 2003, 'Two Indigenous Evanglists: Moses Tjalkobota and Arthur Wellington Clah', The Journal of Religious History 27(3): 348-366.

- 2004, 'Skirmishes in Aboriginal history', Aboriginal History 28: 207-225.

- 2005, 'Introduction' and 'Setting the record straight: new Christian Missions and Mission Christianity', in Indigenous Peoples and Religious Change, Peggy Brock (ed), Brill, Leiden, Boston: 1-11, 107-128.

Brook, J and JL Kohen 1991, Parramatta Native Institution and the Black Town: A History, New South Wales University Press, Kensington.

Burkhart, Louise 1989, The Slippery Earth: Nahua-Christian Moral Dialogue in Sixteenth-century Mexico, University of Arizona Press, Tucson.

Carey, Hilary M 2004, 'Lancelot Threlkeld and missionary linguistics in Australia to 1850 ', in Missionary Linguistics. Selected papers from the First International Conference on Missionary Linguistics, Oslo, 13-16 March 2003, Otto Zwartjes and Even Hovdhaugen (eds), John Benjamins, Amsterdam/ Philadelphia: 253-276.

- 2009, 'Death, God and linguistics: conversations with Missionaries on the Australian frontier, 1824-1845', Australian Historical Studies 40(2): 161-177. 
- and David Roberts 2002, 'Smallpox and the Baiame Waganna of Wellington Valley, New South Wales, 1829-1840: The earliest nativist movement in Aboriginal Australia', Ethnohistory 49(4): 821-869.

Chidester, David 1996, Savage Systems: Colonialism and Comparative Religion in Southern Africa, University Press of Virginia, Charlottesville and London.

Clendinnen, Inga 2005, Dancing with Strangers: Europeans and Australians at First Contact, Cambridge University Press, Cambridge.

Clouten, Keith 1967, Reid's Mistake: The Story of Lake Macquarie from Its Discovery until 1890, Lake Macquarie Shire Council, Lake Macquarie.

Comaroff, Jean and John 1991, Of Revelation and Revolution: Christianity, Colonialism, and Consciousness, vol I, University of Chicago Press, Chicago.

Dixon, RMW 1980, The Languages of Australia, Cambridge University Press, Cambridge.

Douglas, Bronwen 2001, 'Encounters with the Enemy? Academic readings of Missionary narratives on Melanesians', Comparative Studies in Society and History 43(1): 37-64

Elkin, AP 1977, Aboriginal Men of High Degree, Second Edition, University of Queensland Press, St Lucia, Queensland.

Fabian, Johannes 1986, Language and Colonial power: The Appropriation of Swahili in the Former Belgian Congo, 1880 - 1938, Cambridge University Press, Cambridge.

Gardner, Helen Bethea 2006, “"New Heaven and New Earth”: translation and conversion on Aneityum', The Journal of Pacific History 41(3): 293-311

Goodall, Heather 1996, Invasion to Embassy: Land in Aboriginal Politics in New South Wales, 1770-1972, Allen \& Unwin, St Leonards.

Gilmour, Rachel 2006, Grammars of Colonialism: Representing Languages in Colonial South Africa, Palgrave Macmillan, New York.

Greer, Allan 2005, Mohawk Saint: Catherine Tekakwitha and the Jesuits, Oxford University Press, New York.

Hale, Horatio 1846, Ethnology and Philology. United States Exploring Expedition, 1838-1842, vol 6, C. Sherman, Philadelphia.

Hall, Catherine 2002, Civilizing Subjects: Metropole and Colony in the English Imagination 1830 - 1867, University of Chicago Press, Chicago and London. 
Herbert, Christopher 1991, Culture and Anomie: Ethnographic Imagination in the Nineteenth Century, University of Chicago Press, Chicago.

Howitt, AW 1904, The Native Tribes of South-East Australia, MacMillan and Co, London.

Iser, Wolfgang 1996, 'Coda to the discussion', in The Translatability of Cultures: Figurations of the Space Between, Sanford Budick and Wolfgang Iser (eds), Stanford University Press, Stanford.

Jervis, James 1946, 'Lake Macquarie - its discovery and settlement', Journal of the Royal Australian Historical Society 31(2): 101-125.

Johnston, Anna 2003, Missionary Writing and Empire, 1800-1860, Cambridge Studies in Nineteenth-Century Literature and Culture; 8, Cambridge University Press, Cambridge England; New York.

- 2006, 'A blister on the imperial antipodes: Lancelot Edward Threlkeld in Polynesia and Australia', in Colonial Lives Across the British Empire: Imperial Careering in the long nineteenth century, David Lambert and Alan Lester (eds), Cambridge University Press, Cambridge: 58-87.

Keary, Anne 2002, 'Comparing cross-cultural histories: Christianity, translation, and colonialism in Eastern Australia and Northwestern America', unpublished $\mathrm{PhD}$ dissertation, University of California, Berkeley.

- 2006, 'Origins stories: missionary projects and colonial translations in Tahiti, Northwestern America, and Eastern Australia', in Decentering Empire: Britain, India and the Transcolonial world, Dane Kennedy and Durba Ghosh (eds), Orient Longman, New Delhi: 182-212.

Landau, Paul Stuart 1995, The Realm of the Word: Language, Gender, and Christianity in a Southern African Kingdom, Heinemann, Portsmouth, NH.

Lissarague, Amanda 2006, A Salvage Grammar and Wordlist of the Language from the Hunter River and Lake Macquarie, Muurrbay Language and Culture Centre, Nambucca Heads, NSW.

Lohmann, Roger Ivar 2003, Dream Travelers: Sleep Experiences and Culture in the Western Pacific, Palgrave Macmillan, New York.

Magowan, Fiona 2002, “"It is God who speaks in the Thunder...": mediating ontologies of faith and fear in Aboriginal culture', The Journal of Religious History 27(3): 293-310. 
McDonald, Barry 1995, 'Evidence of four New England Corroboree songs indicating Aboriginal responses to European invasion'. Aboriginal History 20: 176-194.

McGregor, William (ed) 2008, Encountering Aboriginal Languages: Studies in the History of Australian Linguistics, Pacific Linguistics, Research School of Pacific and Asian Studies, The Australian National University, Canberra.

Morris, Barry 1989, Domesticating Resistance: The Dhan-Ghadi Aborigines and the Australian State, BERG, Oxford, New York, Munich.

Murray, David 1991, Forked Tongues: Speech, Writing, and Representation in North American Indian Texts, University of Indian Press, Purdue.

Neylan, Susan 2003, The Heavens are Changing: Nineteenth-Century Protestant Missions and Tsimshian Christianity, McGill-Queens University Press, Montreal.

Olender, Maurice 1992, Languages of Paradise: Race, Religion, and Philology in the Nineteenth Century, Trans by Arthur Goldhammer, Harvard University Press, Cambridge, MA.

Perry, TM 1963, Australia's First Frontier:The Spread of Settlement in New South Wales, 1788-1829, Melbourne University Press, Melbourne.

Peterson, Derek 1999, 'Translating the Word: dialogism and debate in two Gikuyu dictionaries', Journal of Religious History 23(1): 31-50.

Porter, Andrew 1999, 'Religion, missionary enthusiasm and empire', in The Oxford History of the British Empire, vol 3: The Nineteenth Century, Andrew Porter (ed), Oxford University Press, Oxford: 222-246.

Rafael, Vicente 1993, Contracting Colonialism: Translation and Spanish Conversion in Tagalog Society under Early Spanish Rule, Duke University Press, Durham and London.

Ranger, Terence 2005, 'Christianity and First Peoples: some second thoughts', in Indigenous Peoples and Religious Change, Peggy Brock (ed), Brill, Leiden, Boston: 15-32.

Reynolds, Henry 1998, This Whispering in Our Hearts, Allen \& Unwin, St Leonards.

Roberts, David Andrew nd, 'Aborigines, commandants, and convicts: the Newcastle Penal settlement', <http://www.newcastle.edu.au/centre/ awaba/awaba/group/amrhd/awaba/history/convicts.html> 
- 2008, “'Language to save the innocent": Reverend L. Threlkeld's linguistic mission', Journal of the Royal Australian Historical Society 94(2): 107-119.

Stanner, WEH 1979, White Man Got No Dreaming: essays 1938 - 1973, Australian National University Press, Canberra.

Swain, Tony 1993, A Place for Strangers: Towards a History of Australian Aboriginal Being, Cambridge University Press, Cambridge.

- and Deborah Rose (eds) 1986, Aboriginal Australians and Christian Missions: Ethnographic and Historical studies, The Australian Association for the Study of Religions, Bedford Park, South Australia.

- and Gary Trompf 1995, The Religions of Oceania, Routledge, New York.

Thomas, Nicholas 1994, Colonialism's Culture: Anthropology, Travel, Government, Polity Press, Cambridge.

Tambiah, Stanley Jeyaraja 1990, Magic, Science, Religion, and the Scope of Rationality, Cambridge University Press, Cambridge.

Van Gent, Jacqueline 2003, 'Changing concepts of embodiment and illness among the Western Arrernte at Hermannsburg Mission', The Journal of Religious History 27(3): 329-347.

van Toorn, Penny 2006, Writing Never Arrives Naked: Early Aboriginal Cultures of Writing in Australia, Aboriginal Studies Press, Canberra.

Woolmington, Jean 1988, “"Writing on the Sand”: the first missions to Aborigines in Eastern Australia', in Aboriginal Australians and Christian Missions: Ethnographic and Historical Studies, Tony Swain and Deborah Bird Rose (eds), Australian Association for the Study of Religions, Adelaide: 77-92.

Worger, William H 2001, 'Parsing God: conversations about the meaning of words and metaphors in nineteenth-century Southern Africa', The Journal of African History 42(3): 417-447. 